\title{
Problems of Translating Definite and Indefinite Articles from English into Arabic
}

\author{
${ }^{1}$ Prof., Lebanese French University, Iraq \\ misbah_alsulaimaan@lfu.edu.krd \\ ${ }^{2}$ Lecturer, Duhok University, Iraq \\ ahmad_hasini8@yahoo.com
}

Dr. Misbah M. D. al-Sulaimaan ${ }^{1}$, Ahmed R. Kh Alsinjari ${ }^{2}$

\begin{abstract}
A study of definite and indefinite articles is one of the most problematic areas in the fields of syntax, grammar, and translation. No doubt, the articles system differs greatly from one language to another, and; therefore one of the biggest problems for translators tackling the translation of articles from English into Arabic is the difficulty of specifying the type of reference each article involves in its cotext and context.

This study mainly aims at: (1) giving a comprehensive study of definite and indefinite articles in English and Arabic; (2) specifying and selecting different samples of definite and indefinite articles from books of English grammar; (3) comparing and contrasting articles systems in English and Arabic; (4) showing the type of reference each article involves in its cotext and context; (5) showing how the specified samples are realized in Arabic; and (6) specifying the method of translation that has been used by the subjects.
\end{abstract}

To achieve the objectives above, the study hypothesizes that: (1) the translation of definite and indefinite articles poses serious problems for translators as well as learners of English and Arabic because of the different types of references these articles involve; (2) since, there is no complete formal correspondence between articles systems in English and Arabic; therefore, translators who adopt a dynamic equivalence are more successful than those who adopt a formal equivalence; and (3) nil-equivalence of indefinite articles between English and Arabic poses serious problems for translators and contrastive analysts.

To test the validity of the hypotheses, this study draws on a miscellany of data sources for its analysis. Sixty seven samples of different patterns with different reference were translated from English into Arabic by six M.A students in the Department of Translation. English texts with their renderings have been analysed by using tables in terms of reference (e.g., generic, specific, and unique) and type of translation methods.

The main findings the study arrived at are: (1) despite the fact that there is a formal correspondence between the English definite article "the" and the Arabic definite article "الت التعريف" on the word rank as well as phrase rank, this generalization does not always work, since in many cases the translation equivalence of the English zero article happens to be definite article in Arabic; (2) with reference to definite generic, reference, a formal correspondence has been achieved between the definite article in English and its equivalence "أل التعربف" in Arabic; (3) as far as definite specific reference is concerned, formal correspondence has been achieved by most subjects with few exceptions. The study ends with some conclusions, suggestions for future studies and recommendations for pedagogical implications. Keyword-definite, indefinite, articles, reference, translation, generic, specific, unique references.

\section{STATEMENT OF THE PROBLEM:}

Much ink has been spilt on the study of definite and indefinite articles in English and Arabic. However, to the best of our knowledge, no work concerning the translation of the articles in question has previously appeared. This thesis is an attempt to fill that gap.

A study of definite and indefinite articles is one of the most problematic areas in the fields of syntax, grammar, and translation. No doubt, the articles system differs greatly from one language to another, and; therefore, one of the biggest problems for translators tackling the translation of articles from English into Arabic is the difficulty of specifying the type of reference (e.g. specific, generic, unique, etc.) each article involves in its cotext and context. 
Incorrect specification of these references result in inappropriate and inaccurate renderings.

\section{AIMS OF THE STUDY}

The present thesis aims at:

(1) Giving a comprehensive study of definite and indefinite articles in English and Arabic.

(2) Specifying and selecting different samples of definite and indefinite articles from books of English grammar which represent different kinds of references.

(3) Comparing and contrasting articles systems in English and Arabic.

(4) Showing the type of reference each article involves in its cotext and context.

(5) Showing how the specified samples are realized in Arabic.

(6) Showing the method of translation that has been used by the subjects.

(7) Proposing new renderings in case the given renderings are inadequate and inaccurate.

(8) Proposing some recommendations for translators and some suggestions for further studies.

\section{HYPOTHES ES}

In the current study, it is hypothesized that:

(1) Translation of definite and indefinite articles poses serious problems for translators as well as learners of English because of the different types of references these articles involve.

(2) Since, there is no formal correspondence between articles systems in English and Arabic; therefore, translators who adopt a dynamic equivalence are more successful than those who adopt a formal equivalence.

(3) Nil-equivalence of indefinite articles between English and Arabic poses serious problems for translators and contrastive analysts.

\section{SCOPE OF THE STUDY}

The current thesis is confined to the study and translation of definite and indefinite articles from English into Arabic. Sixty seven different patterns with different types of references from books of grammar with their six renderings have been chosen as units of analyses because of time and space limits. The study limits itself to a onedirection translation, viz., from English into Arabic.

\section{PROCEDURE AND DATA COLLECTION}

The procedure used in this thesis can be summarized as follows:
(1) A theoretical framework of definite and indefinite articles is made and the semantic ambiguity which arises from the overlap between different types of references has been removed. This may affect the process of translation.

(2) Sixty seven different patterns of articles from books of grammar have been chosen with their renderings by six M.A Students in the Department of Translation in order to compare the SL patterns with their renderings in the TL

(3) A thorough analysis of the SL texts and their renderings in terms of generic reference, specific reference, unique reference and methods of translation are given by means of comprehensive tables.

(4) Findings of texts analyses are discussed and general conclusions are drawn.

\section{VALUE OF THE STUDY}

Translators, translation theorists, students and practitioners of translation can avail of this study when tackling translation of definite and indefinite articles across languages and cultures. It is also expected to be relevant to appropriate cultural interaction, and mutual understanding between English and Arabic cultures and societies. Furthermore, results and conclusions arrived at are anticipated to have theoretical and pedagogical implications for grammarians, translators, syllabus designers and researchers.

\section{ARTICLES: GENERAL PERSPECTIVE}

Every time a noun is used, one has to decide whether or not to use an article, and if it is decided that an article is necessary, then it should be decided which one. In fact these choices are based on a complex interaction of factors including meaning, shared knowledge, context and whether the noun is singular, plural, countable or uncountable (cf. Parrot, 2000: 45 ; Larson, 2000: 71 ; Kremers, 2000: 65 ; Declerck, 2000: 95 and Hansard, 2003: 85).

In many cases; however, fixed expressions and idioms require us to use a particular article (or not to use an article at all), clearly contradicting these "basic rules". Knowing these expressions is a significant factor in using articles correctly (cf. Haegeman and Gueron, 1999: 45, Parrott, 2000: 46 ; and Chung, and Pullum, 2002: 22).

To know how to understand and use articles, it is necessary to focus our attention constantly on how articles are used in texts, beginning with the most accessible and generalisable principles (cf. Reinhart, 1983: 81, Sinclair, 1990: 26 ; Eco, 1995: 64, and Swan, 1996: 98). 
Crystal (2003: 33), in his attempt to show the nature of articles, remarks that articles are subclasses of determiners which display a primary role in differentiating the uses of nouns (e.g. the, a/an in English). Many languages have no article system (e.g. Russian) (cf. Allsop, 1983: 51, Wood and Mcleod, 1990: 77, Crystal, 2003: 33). Of those which draw a distinction, is usually made into definite and indefinite types, partly on semantic and partly on grammatical grounds. As for their positions, articles may appear before the noun (as in English) or after (as in Swedish) (Reimer, 1991: 190, 1992: 375, Radford, 1997: 81, Crystal, 2003: 33). Arabic definite articles also come before nouns.

Parrott (2000: 45) points out that articles belong to the wider class of "determiners", words or phrases that come at the beginning of a noun phrase and signal whether the information is new or familiar, or which tell us something about quantity. Articles in English are either definite (e.g. the) or indefinite (e.g. a/an). Indefinite articles a/an are not two words, but two forms of one word. This is because fixed pronunciation rules determine our choice between them. For instance, whether we use "a" /a/ or "an" /on/ depends on the pronunciation of the sound which immediately follows. If a word begins with a consonant sound, then we should use "a", but if a word starts with a vowel, then we should use "an" (O'Connor, 1980: 94, Roach, 1983: 87, 2002: 87, and Trask, 1993: 120, and 1996: 382).

As for the definite article "the", it is pronounced $/ \delta \partial /$ before consonants, but it is pronounced $/ \delta \mathrm{i} /$ before vowels, e.g.

(1) The problem. /סə probləm/.

(2) The egg. $/ \delta \mathrm{i} \mathrm{eg} /$.

With regard to stressed and isolated forms, we do not usually stress articles, but if they are stressed or if we are isolating the word for some purpose, we also pronounce them differently.

\section{SYSTEM OF ARTICLES USAGE IN ENGLISH AND ARABIC}

English has three types of articles. They are as follows:

(1) The definite article: It is used with all types of nouns such as count nouns both singular and plural, and mass nouns, e.g., the car, the cars, the sugar... etc.

(2) The indefinite article "a (n)" : It is used only with count nouns in the singular, e.g., a car, an orange ... etc.
(3) The zero article (Ø): It is used with plural count nouns and mass nouns, e.g., cars, some cars, water, some water, ...etc. (cf. Huddleston, 1988: 22, Broughton, 1990: 39, AL-Sulaimaan, 2002: 27).

As for Arabic, it seems that there are two contradictory views. According to the first view and general consensus, Arabic has two articles:

(1) The definite article "ال" (the): It is used with all types of nouns such as count nouns, both singular and plural, and mass nouns, e.g., الحليب , السيارات , السيارة , ... etc.

(2) The indefinite article and its forms: With respect to the forms of the indefinite' article morpheme in Arabic, it might be stated that the indefinite article is one of two things: the suffix (-n) which is called "التنوين" (nunnation) and the zero suffix (Ø), which appears only in the deep structure (cf. Beeston, 1970: 65, Wright, 1971: 269, Joodi, 1978, pp. 171, 188 and ALSulaimaan,2002: 27). Nunnation is always realized as

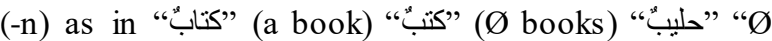
milk" "محمد" " " examples, it seems that Arabic (-n) corresponds to English "a(n)" used with singular count nouns, and (Ø) used with plural count, non-count and proper nouns. On the other hand, Arabic (Ø) corresponds to English "a(n)" used with singular count nouns, and (Ø) used

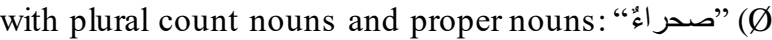
desert) , "مصابيخ" (Ø lamps), "يعقوب" (Ø Jacob (cf. ALSulaimaan, 2002: 27). As far as the second view is concerned, Arabic has three articles namely: definite "الالتتوين" (the)" (nunnation) and zero article (Ø) (see Aziz, 1979: 26, 1989: 96, Kharma \& Hajjaj, 1989: 73 and AL-Sulaimaan, 2002: 28).

From the above mentioned views, it seems that the difference between English and Arabic is that English employs a tripartite system to express definiteness / indefiniteness, namely: a (n), the, and zero, whereas Arabic employs a binary system, namely: "ال" "the" and the indefinite article which has two forms: nunnation (-n) and (Ø). Part of the confusion in using the English articles arises from this main difference between the two systems: Arab learners and translators tend to equate "a(n) (a free morpheme in English) and often with Arabic which apparently seems to be zero (bound morpheme in Arabic), and vice versa. In addition, the use of articles in English is more restricted than in Arabic. In English, it is closely connected with the classification of nouns into count / mass, and singular / plural (see also Zandvoort, 1972: 66, Aziz, 1979: 24, Master, 1988: 2). In Arabic, such classification does not affect the use of articles. Thus, this restriction of 
using articles in English may pose a difficulty for the

Arabic-speaking learners and translators.

\section{REFERENCE VIEWED SEMANTICALLY AND SYNTACTICALLY}

Semantically speaking, reference means the relation that holds between linguistic expressions and what they stand for in the world (or the universe of discourse) on particular occasions of utterance. It is a context-dependent aspect of utterance-meaning: it is a relation that holds between speakers (more generally, elocutionary agents) and what they are talking about on particular occasions. The referential range of referring expressions is fixed by their meaning in the language (i.e., by their sense and denotation). But their actual reference depends upon a variety of contextual factors (Schiffrin, 1994: 39, and Lyons, 2005: 294).

One cannot generally determine the reference of an expression, then, without regard to its context of utterance. What one can do within the restrictions of sentence-based semantics, is to establish the intension of the expression (cf. Cornish, 1986: 51, Lyons, 1991: 67, Hoop, 1992: 28 , Huang, 1994: 90, and Finch, 2000: 93).

Simple propositions are normally analysed by logicians into expressions of two kinds: names and predicates. Names serve to pick out-to refer to-entities (or sets of entities) in some possible world about which statements are being made; predicates serve to ascribe properties to single entities (or sets of entities) and to ascribe relations to ordered pairs, triples, etc., of entities (or sets). All this is formalized in standard predicate logic (cf. Linsky, 1979: 36, Graig, 1986: 85, Chierchia, and McConnell-Ginet 1990: 77, and Potts, 1994: 43).

Names, in the everyday sense of the word "name", are not the only kind of referring expressions. Moreover, from a semantic point of view, they are rather special, in that, of themselves and in languages such as English, they have no descriptive content. (The qualification "in languages such as English" is intended to indicate that natural languages may vary with respect to the way naming operates and is integrated with other cultural practices and customs (yeom, 1998: 50). Philosophical discussions of proper names rarely mention this possibility or its theoretical significance). For example, "Napoleon" is arbitrarily associated with indefinitely many entities (persons, animals, ships, etc.) which in principle have nothing in common. True, one of these entities-or some concept, or intension, associated with him-is, for historical reasons, salient, in the cultures in which English is commonly used. (And some of the others have acquired their names as a consequence of this fact and of its actual or attributed significance in the light of the conventions that regulate the assignment of names in particular cultures) (yeom, 1998: 51). This means that, in default of specific contextual information to the contrary, for most speakers of English the name "Napoleon" will usually be taken to refer to this culturally salient entity. It also means that there will be a whole host of shared associations and connotations clustering around the name "Napoleon", which go to make up what some philosophers refer to as the intension, or individual concept, "Napoleon". However, it does not mean that the name "Napoleon" as such has any descriptive content or sense (for further comments, see Kaplan, 1989: 500, Lyons, 1991: 68 and 2005: 295)

Apart from proper names, there are two main subclasses of referring expressions that are distinguishable, both syntactically and semantically, in English: nounheaded noun-phrases and pronouns. Actually, the traditional analysis of what are called noun-headed noun-phrases (e.g., "the boy" , "those four old houses") can be challenged on both syntactic and semantic grounds. For simplicity, the conventional view will be adopted according to which it is indeed the noun that is the head, or principal constituent, in such phrases: hence the term "noun headed". It is also worth pointing out that the term "noun-phrase" is used in the sense in which it is now commonly used in linguistics. Nounphrases, in this sense, are not necessarily composed of more than one word: i.e., they are not necessarily phrases in the traditional sense of the term "phrase" (for further details, see McCawley, 1976: 68, Matthews, 1981: 36, and Lyons, 2005: 296).

In some languages, words denoting classes of entities can be employed to refer to individuals without any accompanying modifier (definite or indefinite article, demonstrative adjective, etc.): this is not the case in English, where nouns such as "man" or "tree" (count nouns) cannot be employed, without modification by means of a determiner ("the", "that", etc.), a quantifier ("one", etc.) or some more complex expression, to refer to individuals. But languages vary considerably in this respect, and there are many differences of detail among languages which fall into one class (English, French, German, etc.) and languages which fall into another (Russian, Latin, etc.). This fact is mentioned because most of the discussion of referring expressions in general, and of noun-headed nounphrases in particular, in the recent literature is skewed towards languages that behave, syntactically, more or less like English. The treatment of reference in this study is 
highly selective and, of necessity, uses examples from English. It must; therefore, be emphasized the importance of bearing constantly in mind that English is only one of several thousand natural languages, many of which do things differently (Romine, 1985: 11, Poole, 1999: 111, Lyons, 2005: 296).

Noun-headed noun-phrases can be classified semantically in several ways. One subclass to which philosophers have devoted considerable attention is that of definite descriptions: expressions which refer to some definite entity and identify it, in part, by means of the descriptive content of the expression. English examples include "the man" and "John's father". As the term "definite description" suggests, all such expressions may be factorized, semantically if not syntactically and lexically, into two components. One of these, is descriptive (e.g., the word "man" in "in the man"); the other is purely referential (e.g., the definite article "the" in English). Here it will suffice to point out that the referential component is nondescriptive, in that it does not identify the entity that is being referred to by describing any of its contextindependent properties (Potts, 1994: 44, Thomas, 1996: 31, and Lyons, 2005: 297).

The head-noun (e.g., "man" in "the man") in so-called definite descriptions will be more or less descriptive of the referent according to the specificity or generality of its sense. At the limit of generality in English is the word "entity", which can be used to refer to physical and nonphysical (Hoope, 1992: 67) objects and is derived from a Latin word which was deliberately created by philosophers to have exactly the degree of generality that it does have. Since it is descriptively unrestricted, it can combine freely with any other modifying adjective, noun, relative clause, prepositional phrase, etc. But the vast majority of entitydenoting nouns in English are not like this. They fall into "different sortal categories according to what are held to be the essential (or ontologically necessary) properties of the classes of entities that they denote". For example, "thing" denotes a class of inanimate entities, concrete or abstract; "person" denotes a subclass of animate entities of which human beings are the prototypical (though possibly not the sole) members (Hoop, 1992: 67, and Lyons, 2005: 297).

These differences of denotational category (or subcategory) based on actual or assumed ontological differences of kind, quality, process, etc. (which may in part determine and in part be determined by the formal and substantive universals of human cognition) are the source of what has been called categoried incongruity and have distinguished from contradiction (Huddleston, 1984: 28, Lyons, 1991: 70 and 2005: 298).

The two logically separable components of definite descriptions give rise to two different kinds of presupposition: existential and sortal (or categorical). For example, whoever uses the expression "the woman" or "the man", in what we may call, loosely, an ordinary context, is committed to the existential presupposition that the referent exists and the sortal presupposition that it is of a particular sort, or category: the category of persons. It is existential presupposition; however, that has been most extensively discussed in recent years by both philosophers and linguists (Lyons, 2005: 298). The reason is that the violation of an existential presupposition, unlike the violation of a sortal presupposition (e.g., Quadruplicity drinks procrastination. Thursday is in bed with Friday) cannot be accounted for as being in any way anomalous within the framework of sentence-based semantics. To take the now famous example: there is nothing wrong with the sentence.

(1) "The (present) king of France is bald".

It is in the utterance of this sentence (to make a statement) at a time when there is no king of France that the existential presupposition is violated (Allwood, et al, 1985: 116; and Langacker, 1987: 72, and Lyons, 1991: 71, and 2005: 298).

We shall not go into the various controversies associated with the notion of existential presupposition. We will simply point out that, on the view of sentences, utterances and propositions taken in this study, anyone who deliberately violates an existential presupposition in using what purports to be a definite description fails to express any proposition at all. Looked at in this way, much of the recent discussion of presupposition by philosophically minded semanticists, important though it may appear to those who are committed to a strictly truth-conditional theory of meaning, is of secondary importance in linguistic semantics. But there are, none the less, one or two important points to be made in this connexion (Cann, 1993: 54, O'Grady, et al, 1997: 28, and Lyons, 2005:298).

First, it is not just definite descriptions that involve existential presuppositions, but referring expressions of all kinds. Reference is intrinsically connected with existence; one cannot successfully refer to something that does not exist. One can, of course, successfully refer to imaginary, fictional and hypothetical entities; but in so doing, one presupposes that they exist in an imaginary, fictional or hypothetical world. Similarly, one can (and frequently does) refer to dead persons. One can refer to them in a past-tense sentence as existent in a world (or state of the world)which 
itself no longer exists (e.g., Socrates was condemned to death in 399 BC for "allegedly" corrupting the young men of Athens). More interestingly, one can refer to them as existent in the present world in literature or oral tradition (e.g., Socrates tells us "in the works of Plato" that noone does wrong knowingly or voluntarily) (for further comments, see Cann, 1993: 55, Samovar and Porter, 2002: 91, and Lyons, 2005: 299).

Second, the falsity of the descriptive content of a referring expression, whether it is a definite description or not-does not nullify the act of reference and render it void. One can successfully, but mistakenly, refer to someone or something by means of a description which, as it happens, is false Jackendoff, 2001: 87, Marten, 2002: 94 and Lyons, 2005: 300). Let us suppose-to adopt and modify a now famous example-that $\mathbf{x}$ and $\mathbf{y}$ are at a cocktail party and that $\mathbf{x}$ notices some third person, $\mathbf{z}$, holding in his hand a tumbler filled with a colourless liquid and also containing ice and lemon. In these circumstances $\mathbf{x}$ might successfully refer to $\mathbf{z}$ for the benefit of $\mathbf{y}$ by using the expression "the man (over there) drinking gin and tonic". Here it is sufficient to note that, whether an expression of this kind is added to the definite description or not, in the circumstances envisaged there will commonly be some gesture or other signal drawing the addressee's attention to the referent. Let us now further suppose that, as a matter of fact, z's glass contains, not gin and tonic, but water (and even that $\mathbf{z}$ is not drinking it, but merely holding it for someone else). The fact that the descriptive content of "the man drinking gin and tonic" is false does not mean that $\mathbf{x}$ has failed to refer to $\mathbf{z}$. If $\mathbf{y}$ successfully identifies $\mathbf{z}$ as the intended referent, $\mathbf{x}$ has successfully referred to $\mathbf{z}$. Indeed, $\mathbf{x}$ need not be mistaken about the facts in order to refer successfully (but falsely) to z. There are all sorts of everyday situations in which, out of politeness or for other reasons, we refer to people, animals or things by means of descriptions that we know or believe to be false. In short, the actual truth or falsity of the descriptive content of a referring expression is not directly relevant to its success. Normal human interaction is governed by a set of culturally determined conventions, amongst which truthfulness is often very properly moderated by politeness. (Jackendoff, 2001: 87, Marten, 2002: 94, and Lyons, 2005: 300).

What should be emphasized is that definite descriptions, more obviously that proper names, are context-dependent. Their use as referring expressions cannot be satisfactorily accounted for solely within the framework of sentence-based truth-conditional semantics. When speakers employ a definite description, they indicate by means of the referential part of the expression that they are performing an act of reference, and, in doing so, they tacitly assure the addressee that the descriptive part of the expression will contain all the information that is required, in context, to identify the referent (cf. Kadmon, 1990: 280, Ioup, 1997: 240, and Lyons, 2005: 300).

Here it is sufficient to note that such generally accepted de re / de dicto ambiguities of the kind illustrated here give us particularly cogent reasons for extending the theory of reference beyond the bounds of what have been loosely and inadequately called ordinary contexts. Indeed, it is arguable that there is much more intensionality involved in so-called ordinary contexts than is generally supposed (Kripke, 1977: 70, 1980: 55, and Lyons, 2005: 302).

\section{RFFERENCE AND ARTICLES IN ENGLISH AND ARABIC}

Articles belong to the wider class of "determiners", words or phrases that come at the beginning of a noun phrase and signal whether the information is new or familiar, or which tell us something about quantity (Aziz, 1979: 27, 1989: 95, Azar, 1992: 206, Leech and Svartvik, 1994: 237, Biber et al., 2000: 263).

English uses three types of articles. They are as follows:

(1) The Definite Article "the": It is used to express definiteness for all kinds of nouns (i.e., countable nouns both singular and plural as well as mass nouns) (Neuman, 1981: 12, Azar, 1992: 207, and Murphy and Smalzer, 2003: 132). The following table is illustrative

Table.5: Use of Definite Article with Nouns

\begin{tabular}{|l|l|l|l|}
\hline No. & Title & Examples & Function \\
\hline 1. & Singular Count Nouns & The ball, The exam & Definite Meaning \\
\hline 2. & Plural Count Nouns & The balls, The exams & Definite Meaning \\
\hline 3. & Mass Nouns & The gold, The knowledge & Definite Meaning \\
\hline
\end{tabular}

(2) The Indefinite Article "a/an": It is used to express indefinite meaning of singular count nouns (Heim,1987:25, 1991: 56, 1992: 190). The following table is interesting. 
Table.6: Use of Indefinite Article with Nouns

\begin{tabular}{|l|l|l|}
\hline Title & Example & Function \\
\hline Singular Count Noun & A garden, an orange & Indefinite Meaning \\
\hline
\end{tabular}

(3) Zero Article "Ø" or Unstressed "Some": They are used to express indfinite meaning of plural count nouns and of mass nouns (Ward and Prince, 1991: 170, Wilson, 1997: 50, and Yeom, 1998: 59). Let us consider the following table.

Table.7: Use of Zero Article with Nouns

\begin{tabular}{|l|l|l|l|}
\hline No. & Title & Example & Function \\
\hline $\mathbf{1 .}$ & Plural Count Nouns & $\begin{array}{l}\text { (some) plates, } \\
\text { (some) spoons }\end{array}$ & Indefinite meaning \\
\hline $\mathbf{2 .}$ & Mass Nouns & $\begin{array}{l}\text { (some) gold, } \\
\text { (some) knowledge }\end{array}$ & Indefinite meaning \\
\hline
\end{tabular}

It has been pointed out that determiners, of which the articles are central, determine the reference of the noun with which they are used. Let us consider the following examples.

(1) An aeroplane is faster than a car.

(2) I found a ring.

In example (1) an aeroplane does not refer to any specific aeroplane. It refers to the whole class of aeroplanes. This reference is called "generic reference". In example (2), on the other hand, the noun phrase "a ring" refers to a specific ring; its reference is ; therefore, termed "specific reference". The difference between these two references obtains in the plural as well, e.g.

(3) Aeroplanes are faster than cars.

(4) I found (some) rings.

\section{ARTICLES AND GENERIC REFERENCE IN ENGLISH AND ARABIC}

Reference is generic when a noun phrase refers to a whole class rather than to an individual person or thing (Heim, 1991: 56, Enc, 1991: 4, and Benita, 2004: 73). Let us consider the following examples about generic reference.

1. Horses are intelligent animals (Horses in general).

2. A doctor is not better than his patient) (Doctors and patients in general).

3. Beer is, quite rightly, Britain's favourite Friday night drink. (Beer in general and not specific beer).

4. The Americans are very jealous because they have not got a Royal Family of their own.

Generic "the" takes place with plural noun phrases in two special cases:

a) Nationality Nouns: i.e., noun phrases referring to the people of a nationality, an ethnic group, etc., e.g.

1. The Japanese are short .

(generic)

2. The Russians are tall .

(generic)
3. The Welsh are fond of singing - (generic)

b) Phrases with an adjective head referring to a group of people, e.g.

1. The unemployed . (people who are unemployed)

2. The poor . (poor people in general)

3. The blind . (blind people in general)

By contrast, the indefinite article has a distinctly limited role in conveying generic meaning, since it tends in non-referring use to carry a general partitive implication (such that "a" means "any") which may in certain contexts be merely tantamount to a generic (Heim, 1991: 57 and Enc, 1991: 4). The limitations on generic implication can be seen in comparing the following examples:

1. Tigers run more gracefully than most animals .

2. A tiger runs more gracefully than most animals.

3. Tigers are becoming extinct . But note :

4. *A tiger is becoming extinct .

With regard to the generic use of the zero article, the following examples are illustrative .

1. Cigarettes are bad for your health .

2. Hydrogen is lighter than Oxygen .

From examples (1) and (2), one can say that the generic use of zero article with both plurals nouns (example 1) and noncount nouns (example 2) identifies the class considered as an "undifferentiated whole"(Quirk et al., 1985: 272).

As for Arabic, the definite article "أل التعريف" is used with a noun to indicate generic reference, e.g.
1. (The dog) .
2. الكلاب (The dogs).
3. (water) . 
Arabic may use partial generic reference which is expressed by a noun. Such nouns have "zero article", e.g.

1. (The future of humanity).

2. قطن مصر الانسالة الغربة

3. (The politics of the western

Countries) .

The adjectival "equivalent" takes the definite article, e.g.

4. (Humanity History).

5. (English \{Poetry) .

(for further details, see Aziz, 1989: 106)

As it has been mentioned earlier, the singular and the plural are neutralized in generic reference, and the dual number is always specific whether definite or indefinite, e.g.

1. (I picked up the two flowers) (definite specific) .

2. (I picked up two flowers) (indefinite specific) . (cf. Aziz,

1989: 106).

One can come to the conclusion that English uses three articles (i.e., the definite / indefinite / zero) for expressing generic reference, whereas Arabic uses the definite article with all types of common nouns for expressing the generic reference. The following table is illustrative .

Table.12: Generic Reference in English and Arabic:

\begin{tabular}{|c|c|c|c|c|c|}
\hline language & Article & Examples & Renderings & Article & language \\
\hline \multirow{3}{*}{ English } & Definite & $\begin{array}{l}\text { The car became an } \\
\text { increasing } \\
\text { necessity of life. }\end{array}$ & أصن ضرت السيارة ضرورة & Definite & \multirow[b]{3}{*}{ Arabic } \\
\hline & Indefinite & $\begin{array}{l}\text { A car became an } \\
\text { increasing } \\
\text { necessity of life. }\end{array}$ & من ضرور ألصيارة ضرورة & Definite & \\
\hline & Zero & $\begin{array}{l}\text { Cars became an } \\
\text { increasing } \\
\text { necessity of life. }\end{array}$ & من ضرور الصيار الحيات ضرورة & Definite & \\
\hline
\end{tabular}

\section{SPECIFICITY: PRAGMATIC OR} SEMANTIC ?

It has been observed that indefinites have various uses. One of them is the one which gives a generic reading.

\section{A dog is clever.}

In this sentence, the indefinite $\mathbf{a} \mathbf{d o g}$ cannot refer to a specific dog. Rather the sentence is generic, expressing a property of the canine species.

There is another use of indefiniteness.

2. A: Does John have a dog ?

B: Yes, he has one / ?? it.

A's question can be roughly interpreted as follows:

3. Does John have any dogs?

This is the use which is traditionally called a quantificational use of indefiniteness. The question is not about a particular dog, and so it is odd to refer to the dog by a pronoun like it. Instead, the pronoun one is used to denote an arbitrary dog (cf. Abusch, 1994: 90, and Yeom, 1998: 41).

This can be compared with the following discourse.

4. A friend of mine is going to graduate soon. He is very smart.

The indefinite is generally regarded as specific. Specificity has been characterized as the speaker having an individual in mind. In other words, when the speaker utters the sentence, he seems to have a particular friend in mind. In this case, the indefinite allows for using a pronoun he in order to refer to the specific friend (Enc, 1991: 25 and Yeom, 1998: 4).

The issue I am interested in is restricted to the uses of indefinites illustrated in (2) and (4) I will not discuss indefinites which are interpreted as generic. The Discussion begins with the issue of whether the two uses of indefinites which are illustrated in (2) and (4) reflect semantic ambiguities. This distinction is not clear-cut. Let's look at the following discourse:

5. John has a dog. It is black and white.

It seems that the indefinite $\underline{\mathbf{a ~ d o g}}$ can be interpreted as quantificational. These two sentences can be true in a situation where the speaker hears that John has $\underline{\mathbf{a} d o g}$ which is black and white. It may be that John has more than one

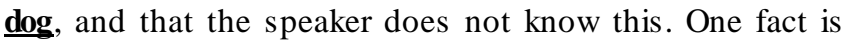
that it is possible for the speaker not to have a particular dog in mind. Still it allows for the use of the pronoun it.

There is some evidence that shows that pragmatic factors intervene in the use of pronouns.

6. [At least one student] is going to present a paper. $\underline{\mathrm{He}}$ is well aware of 
the problems with the paper.

If the quantifier at least one student cannot be about a particular student, there may be no possibility that a student can be picked out by what is actually expressed. In (6), however, the speaker can use the pronoun he to refer to a student. This would be strange if the speaker had no student in mind when he utters the first sentence. A still more interesting case arises when the two sentences are uttered by two different speakers. In the following conversation, $\mathrm{A}$ is talking to $\mathrm{C}$, but in the middle of it, $\mathrm{B}$ is intruding into the conversation and asking a question.

7. A: At least one student is going to present a paper.

$\mathrm{B}$ : Is he aware of the problems with the paper?

In ordering situations, B's question is odd. If use of the quantifier at least one student allows for the use of the pronoun, there is no reason the pronoun makes B's utterance odd. B's question becomes acceptable only when $\mathrm{B}$ knows what student $\mathrm{A}$ is talking about and $\mathrm{A}$ also knows that B knows who A is talking about. In this sense, the use of the pronoun not only is linguistically determined, but needs pragmatic consideration (Heim, 1992: 190 and Yeom, 1998: 5).

Despite pragmatic consideration, indefinites must be distinguished from a quantifier like at least one student. Let's look at the following conversation.

8. A: John has a dog .

B: Is it black and white?

Even when B does not know which $\operatorname{dog} \mathrm{A}$ is talking about, he can use the pronoun it. This does not mean that an indefinite allows for a pronoun like it even if the indefinite is used in a quantificational reading. We have already witnessed that in some cases where an indefinite is quantificational, one is used. Closer scrutiny reveals that still some other pragmatic factor is involved in the use of the pronoun in (8). A's statement is semantically true when John has two or more dogs., but in this situation B's question is infelicitous. Even if A's statement asserts that John has at least one dog, B understands it as implicating that John has only one dog considering the possibility that if John had two or more dogs and A knew it, he would make a different utterance (Ward and Prince, 1991: 170 and Yeom, 1998: 5).

In order to see whether indefinites are ambiguous, we have to find cases where pragmatic factors cannot intervene. It is hard to come up with such cases since in making utterances we are always supposed to follow some pragmatic principles. For this reason, it is difficult to examine indefinites as to whether or not they are ambiguous (cf. Diesing, 1992: 50).

\section{ARTICLE AND SPECIFIC REFERENCE IN ENGLISH AND ARABIC}

Tackling specific reference, a distinction must be first drawn between indefinite and definite reference. In indefinite specific reference, the indefinite article "a/an" is used with singular nouns and zero article or the unstressed indefinite "some" is used with plural and mass nouns (see 208), e.g.

1. I saw $\underline{\text { a girl }}$ and $\underline{\text { a boy }}$ standing under $\underline{\text { a tree. }}$ (indefinite specific reference).

2. I found (some) girls and (some) boys playing in a garden. (indefinite specific reference).

3. Joe has been chasing (some) women ever since he was young.

4. I would like to have (some) coffee or (some) tea. (indefinite specific reference).

In regard to definite specific reference, it can be expressed by using the definite article before singular and plural count nouns as well as mass nouns. Let us consider the following examples.

1. When the policeman had gone, I remembered that I had not told him about the damaged window-pane. (definite specific reference).

2. Would the children like to go out and play ? (definite specific reference).

3. Oh dear! The ink has not come out of the carpet. (definite specific reference).

In sentences (1), (2) and (3) the identity of the particular "policeman", "damaged window-pane", "children", "ink", "carpet" is obvious because they are physically present and visible. But the reference might be obvious because the situational reference was in the minds of addressor and addressee (Quirk et al., 1972: 154, 1985, 274, Greenbaum and Quirk, 1990: 78 and Biber et al., 2000: 267).

As for Arabic, it seems that the indefinite and definite specific reference can be expressed by using zero Article and the definite article respectively (Aziz, 1979: 20, 1989: 105, Ilyas, 1985: 52, Kremers, 2000: 69), e.g.

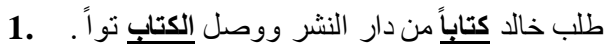

(Khalid ordered a book from the publisher and the book has just arrived).

The definite article can also be used for what is given in the situational context, e.g. 
1. هل أطعمت القطة ؟ (Have you fed the cat ?) said in a domestic context).

2. هل زرت القلعة ؟ (Have you visited the castle ?) (said in a given town).

In Arabic, definite specific nouns can be placed in construct to another noun take zero article: the definite article is attached to the second noun and it is called in Arabic "التعريف بالإضافة" , (cf. Beeston, 1970: 115, Wright, 1971: 178, Joodi, 1978: 50, Aziz, 1989: 106, Al-Naqqash, 2000: 115).

1. سيارة المدرس (the teacher's car).

2. مظلة الطالبة (the student's umbrella).

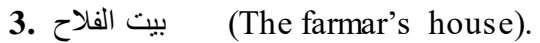

4. أزهار الحديقة (The flowers of the garden).

In Arabic, one can also draw a distinction between linguistic reference and situational reference. Linguistic reference may be either anaphoric or Cataphoric. The following examples are illustrative.

1. زرع محمد وردة و زهرة ثم قطف الزهرة
(Muhammed planted a rose and a flower. Then he picked up the flower)

(Linguistic Reference).

2. أين غرفة الانتظار ؟ (Where is the waiting room ?) (Situational Reference).

3. كتب خالد مقالة و قصيدة ثم قر أ القصبدة

(Khalid wrote an essay and a poem. Then he read the poem) (Anaphoric

Reference)

4. . الكتاب الذي على المنضدة مفيد (The book on the table is useful) (Cataphoric

Reference).

As for dual number, it is by definition specific, e.g.

1. زرعت وردنين (I planted two roses) (Indefinite specific Reference).

(cf. Aziz, 1979: 21 and 1989: 106, and Henkin, 1998: $50)$.

One can illustrate the distinction between specific reference both definite and indefinite by using the following tables.

Table.13: Definite Specific Reference in English and Arabic

\begin{tabular}{|c|c|c|c|c|c|}
\hline Language & Article & Examples & Examples & Article & Language \\
\hline \multirow{4}{*}{ English } & \multirow{4}{*}{ Definite } & 1. I bought the flower. & 1. اشتريت الزهرة & \multirow{4}{*}{ Definite } & \multirow{4}{*}{ Arabic } \\
\hline & & 2. I bought the flowers. & 2. اشتريت الأزهار & & \\
\hline & & $\begin{array}{l}\text { 3. I bought the two } \\
\text { flowers. }\end{array}$ & 3. اشتريت الزهرتين & & \\
\hline & & 4. I bought the sugar. & 4. اشتريت السكر & & \\
\hline
\end{tabular}

Table.14: Indefinite Specific Reference in English and Arabic

\begin{tabular}{|c|c|c|c|c|c|}
\hline Language & Article & Examples & Examples & Article & Language \\
\hline \multirow{4}{*}{ English } & Indefinite & 1. I bought a flower. & 1. اشتريت زهرة & \multirow{4}{*}{ Zero } & \multirow{4}{*}{ Arabic } \\
\hline & $\begin{array}{l}\text { (some) } \\
\text { Zero }\end{array}$ & $\begin{array}{l}\text { 2. I bought (some) } \\
\text { flowers. }\end{array}$ & 2. اشتريت أزهارا & & \\
\hline & & $\begin{array}{l}\text { 3. I bought (some) } \\
\text { sugar }\end{array}$ & 3. اشتريت سكرا & & \\
\hline & & \begin{tabular}{|lrr}
$4 . \quad$ I & bought & two \\
flowers & & \\
\end{tabular} & 4. اشتريت زهرتين & & \\
\hline
\end{tabular}

\subsection{Articles and Unique Reference In English and Arabic:}

Proper nouns are basically "names", by which we understand the designation of specific people (Dickens), places (London) months (March), days (Friday) holidays (Christmas), magazines (Times), and so forth. Names have "unique" reference, and do not generally share the formal characteristics of common nouns. In particular, they lack articles, or rather article contrast:

London $\sim$ *the London $\sim$ *a London

The Hague $\sim *$ Hague $\sim *$ a Hague

Names reflect their uniqueness of reference in writing by our use of initial capitals. This device enables us to raise to the uniqueness of proper noun status such concepts as 
"Fate" , "Fortune" , "Heaven" , "Hell" ,"Truth" ,"Nature",

"Paradise". These are sometimes written with initial capital letter (Quirk et al, 1972: 160, 1985: 288, Greenbaum and Quirk, 1990: 87, Biber et al., 2000: 266).
Sometimes, names have restrictive modification to give a partitive meaning to the name, proper nouns take the (cataphoric) definite article.

Table.15: Unique and Partitive Meaning

\begin{tabular}{|l|l|l|l|}
\hline No. & Unique Meaning & No. & Partitive Meaning \\
\hline 1. & during Easter & 1. & during the Easter of that year \\
\hline 2. & in Elizabethan England & 2. & in the England of Queen Elizabeth \\
\hline 3. & in Denmark & $\mathbf{3 .}$ & in the Denmark of today \\
\hline 4. & Chicago & $\mathbf{4 .}$ & the Chicago I like \\
\hline 5. & Dickens & $\mathbf{5 .}$ & the young Dickens \\
\hline
\end{tabular}

Unique reference uses zero article. The proper noun may be a personal name (e.g. Lady Churchill, Milton), a temporal name (e.g. Easter, Christmas), a geographical name (e.g. (north) American, (medieval) Europe), a name + common noun (e.g. Oxford Street, Scotland Yard).

Some proper nouns are preceded by a definite article, e.g., The Wilsons, The Netherlands, The Suez Canal, etc. (Quirk et al, 1972: 160, 1985: 288, Quirk and Greenbaum, 1973: 112, and Greenbaum and Quirk, 1990: 87).

As for Arabic, unique reference points to a single individual and is expressed by zero article used with proper nouns: دمشق , عمر , حلب , أربيل

A number of proper nouns such as geographical place names can take the "definite article", e.g. , القدس , الديوانية despite the fact that the "zero article" is also used in spoken colloquial language: قدس , ديو انية , ناصرية.

The proper noun may be converted to a common noun with a change in its reference by placing it in construct to another noun. The zero article is used and the noun phrase has generic reference, e.g. سيبويه زمانه (The Sibawayhi of his age) باريس الثرق (The Paris of the East). If the proper noun originally takes the definite article, the article is dropped, e.g.

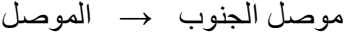

$$
\begin{aligned}
& \text { (Aziz, 1989: 106). }
\end{aligned}
$$

One can draw a distinction between unique reference in English and Arabic by using the following table.

Table.16. Unique Reference in English and Arabic

\begin{tabular}{|c|c|c|c|c|c|}
\hline language & Article & Examples & Examples & Article & language \\
\hline \multirow{6}{*}{ English } & & 1. The Wilsons & 1. الناصرية & \multirow{3}{*}{ Definite } & \multirow{6}{*}{ Arabic } \\
\hline & Definite & 2. The Netherlands & 2. القدس & & \\
\hline & & 3. The Suez Canal & 3. الديوانية & & \\
\hline & \multirow{3}{*}{ Zero } & 1. Milton & 1. عمر & \multirow{3}{*}{ Zero } & \\
\hline & & 2. Medieval Europe & 2. دمشق & & \\
\hline & & 3. Oxford Street & 3. اربيل & & \\
\hline
\end{tabular}

\section{THE MODEL ADOPTED}

From our literature review that tackled the specification of definite and indefinite articles, one can say that this topic has been studied from different points view, namely syntactic, semantic and logical. In fact, depending on one level or view is not sufficient to grasp the whole subject; therefore, we will adopt an eclectic approach in order to specify the accurate and exact types of references for the articles in question.

\subsection{The Concept of Translation:}

The term translation itself has several meanings: it can refer to the general subject field, the product (the text that has been translated) or the process ( the act of producing the translation, otherwise known as translating). The process of translation between two different written languages involves the translator changing an original written text (the source text or ST) in the original verbal language (the source language or SL) into a written text (the target text or TT) in a different verbal language (the target language or TL). This type corresponds to 'interlingual translation' and is one of the three categories of translation desribed by the 
Russian-American structuralist Roman Jakobson in his seminal paper 'On linguistic aspects of translation' (Jakobson 1959: 114). Jakobson's categories are as follows:

1. intralingual translation, or 'rewording' : 'an interpretation of verbal signs by means of other signs of the same language'.

2. interlingual translation, or 'translation proper' : 'an interpretation of verbal signs by means of some other language' .

3. intersemiotic translation, or 'transmutation' : 'an interpretation of verbal signs by means of signs of nonverbal sign systems'.

Intralingual translation would occur for example, when we rephrase an expression or text in the same language to explain or clarify something we might have said or written. Intersemiotic translation would occur if a written text were translated, for example, into music, film or painting. It is interlingual translation which is the traditional, although by no means exclusive, focus of translation studies (for further comments, see Kussmaul, 1995: 60).

\subsubsection{Formal and Dynamic Equivalence and the} Principle of Equivalent Effect:

The old terms such as 'literal', 'free' and 'faithful' translation, are discarded by Nida in favour of 'two basic orientations' or 'types of equivalence' (Nida 1964: 159): (1) formal equivalence and (2) dynamic equivalence. These are defined by Nida as follows:

\subsubsection{Formal Equivalence:}

Formal equivalence focuses attention on the message itself, in both form and content. One is concerned that the message in the receptor language should match as closely as possible the different elements in the source language (Nida 1964: 159).

Formal equivalence is thus keenly oriented towards the ST structure, which exerts strong influence on determining accuracy and correctness. Most typical of this kind of translation are 'gloss translations', with a close approximation to ST structure, often with scholarly footnotes, allowing the student in an academic environment to gain close access to the language and customs of the source culture.

\subsubsection{Dynamic Equi valence:}

1. No one knows precisely when the wheel was invented. (Quirk et al, 1985: 282).
Dynamic equivalence is based on what Nida calls 'the principle of equivalence effect', where 'the relationship between receptor and message should be substantially the same as that which existed between the original receptors and the message' (Nida 1964: 159). The message has to be tailored to the receptor's linguistic needs and cultural expectation and 'aims at complete naturalness of expression' 'Naturalness' is a key requirement for Nida. Indeed, he defines the goal of dynamic equivalence as seeking 'the closest natural equivalence to the sourcelanguage message' (Nida 1964: 166, Nida and Taber 1969: 12). This receptor-oriented approach considers adaptations of grammar, of lexicon and of cultural references to be essential in order to achieve naturalness; the TT language should not show interference from the SL, and the 'foreignness' of the ST setting is minimized in a way that would now be criticized by later culturally oriented translation theorists (Newmark;, 1988a, 1988b, 1991, Bell, 1991, Baker, 1992, Farghal, 1993, and Hatim and Mason, 1997, and Farghal and Shunnaq, 1999).

For Nida, the success of the translation depends above all on achieving equivalent response. It is one of the 'four basic requirements of translation', which are :

1. making sense;

2. conveying the spirit and manner of the original ;

3. having a natural and easy form of expression ;

4. producing a similar response .

It is interesting to note the similarity with Tytler's principles of translation in one of the early attempts at systematizing translation theory at the end of the eighteenth century (Kamal, 1999: 45, Ke, 2001: 7, Karamanian, 2005: 250).

Although dynamic equivalence is aimed at, it is also a graded concept since Nida accepts that the 'conflict' between the traditional notions of content and form cannot always be easily resolved. As a general rule for such conflicts, Nida underlines that 'correspondence in meaning must have priority over correspondence in style' if equivalent effect is to be achieved. (See also, Kussmaul, 1995: 60 and Hongwei, 1999: 50).

1.16.2 Data Analysis:

1.16.2.1 Generic Reference / Definite:

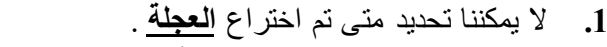

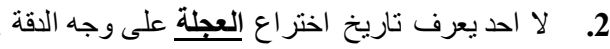

$$
\begin{aligned}
& \text { 3. }
\end{aligned}
$$

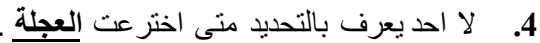

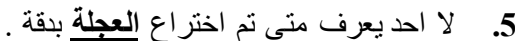


Text Analysis (1):

\begin{tabular}{|c|c|c|c|c|c|c|c|c|c|c|}
\hline \multirow{3}{*}{ Title } & \multirow{4}{*}{ No } & \multicolumn{7}{|c|}{ Reference } & \multicolumn{2}{|c|}{ Trans. } \\
\hline & & \multicolumn{3}{|c|}{ Generic } & \multicolumn{3}{|c|}{ Specific } & \multirow{2}{*}{ Unique } & \multirow{2}{*}{ FE. } & \multirow{2}{*}{ DE } \\
\hline & & definite & Indefinite & Zero & definite & Indefinite & Zero & & & \\
\hline $\begin{array}{l}\text { SL Text } \\
\text { English }\end{array}$ & & + & & & & & & & + & \\
\hline \multirow{6}{*}{$\begin{array}{c}\text { TL Texts } \\
\text { Arabic }\end{array}$} & 1 & + & & & & & & & + & \\
\hline & 2 & + & & & & & & & + & \\
\hline & 3 & + & & & & & & & + & \\
\hline & 4 & + & & & & & & & + & \\
\hline & 5 & + & & & & & & & + & \\
\hline & 6 & + & & & & & & & + & \\
\hline
\end{tabular}

The Proposed Rendering:

لا احد يعلم بالتحديد متى اخترعت العجلة. .

2. He spoke with the consummate as surance and charm of the successful Harley Street Surgeon. (Quirk et al, 1985: 283).

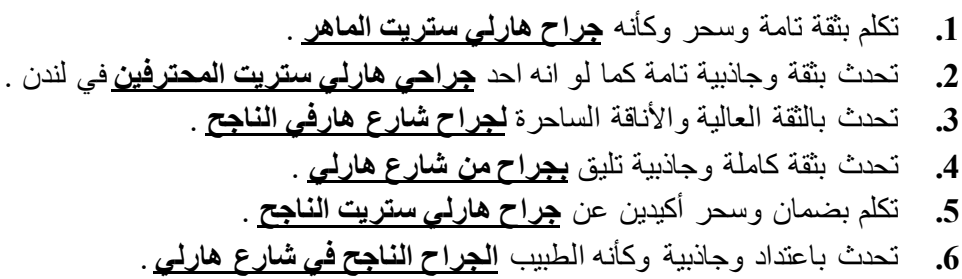

Text Analysis (2):

\begin{tabular}{|c|c|c|c|c|c|c|c|c|c|c|}
\hline \multirow{3}{*}{ Title } & \multirow{4}{*}{ No } & \multicolumn{7}{|c|}{ Reference } & \multicolumn{2}{|c|}{ Trans. } \\
\hline & & \multicolumn{3}{|c|}{ Generic } & \multicolumn{3}{|c|}{ Specific } & \multirow{2}{*}{ Unique } & \multirow{2}{*}{ FE } & \multirow{2}{*}{ DE. } \\
\hline & & definite & Indefinite & Zero & definite & Indefinite & Zero & & & \\
\hline $\begin{array}{l}\text { SL Text } \\
\text { English }\end{array}$ & & + & & & & & & & & \\
\hline \multirow{5}{*}{$\begin{array}{c}\text { TL Texts } \\
\text { Arabic }\end{array}$} & 1 & + & & & & & & & + & \\
\hline & 2 & + & & & & & & & + & \\
\hline & 3 & + & & & & & & & + & \\
\hline & 4 & & + & & & & & & & + \\
\hline & 5 & + & & & & & & & + & \\
\hline
\end{tabular}


The Proposed Rendering:

3. The evil is always defeated. (Quirk et al, 1972: 151).

تحثث بثقة وجاذبية تامتين كما لو انه كان احد جراحي شارع هارلي المحترفين.

$$
\begin{aligned}
& \text { 1. اتمة الثر الخذلان . } \\
& \text { 2. } \\
& \text { 3. } \\
& \text { 4. الشبر منهزم لا محالة . } \\
& \text { 5. } \\
& \text { 6. يُهزم الثر دائماً. . }
\end{aligned}
$$

\begin{tabular}{|c|c|c|c|c|c|c|c|c|c|c|}
\hline \multirow{3}{*}{ Title } & \multirow{4}{*}{ No } & \multicolumn{7}{|c|}{ Reference } & \multicolumn{2}{|c|}{ Trans. } \\
\hline & & \multicolumn{3}{|c|}{ Generic } & \multicolumn{3}{|c|}{ Specific } & \multirow{2}{*}{ Unique } & \multirow{2}{*}{ FE } & \multirow{2}{*}{ DE } \\
\hline & & definite & Indefinite & Zero & definite & Indefinite & Zero & & & \\
\hline $\begin{array}{l}\text { SL Text } \\
\text { English }\end{array}$ & & + & & & & & & & & \\
\hline \multirow{6}{*}{$\begin{array}{c}\text { TL Texts } \\
\text { Arabic }\end{array}$} & 1 & + & & & & & & & + & \\
\hline & 2 & + & & & & & & & + & \\
\hline & 3 & + & & & & & & & + & \\
\hline & 4 & + & & & & & & & + & \\
\hline & 5 & + & & & & & & & + & \\
\hline & 6 & + & & & & & & & + & \\
\hline
\end{tabular}

Text Analysis (3):

The Proposed Rendering:

4. The Welsh are fond of singing. (Quirk et al, 1985: 284).

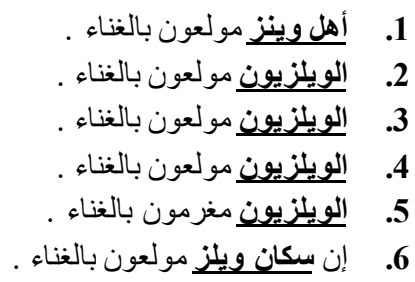

Text Analysis (4):

\begin{tabular}{|c|c|c|c|c|c|}
\hline \multirow{2}{*}{} & \multirow{2}{*}{} & Reference & & \\
\cline { 3 - 5 } & Generic & Specific & & \\
\cline { 3 - 6 } & & & & \\
\hline
\end{tabular}




\begin{tabular}{|c|c|c|c|c|c|c|c|c|c|c|}
\hline Title & No & definite & Indefinite & Zero & definite & Indefinite & Zero & Unique & FE & $\overline{D E}$ \\
\hline $\begin{array}{l}\text { SL Text } \\
\text { English }\end{array}$ & & + & & & & & & & & \\
\hline \multirow{6}{*}{$\begin{array}{c}\text { TL Texts } \\
\text { Arabic }\end{array}$} & 1 & + & & & & & & & + & \\
\hline & 2 & + & & & & & & & + & \\
\hline & 3 & + & & & & & & & + & \\
\hline & 4 & + & & & & & & & + & \\
\hline & 5 & + & & & & & & & + & \\
\hline & 6 & + & & & & & & & + & \\
\hline
\end{tabular}

\section{The Proposed Rendering:}

5. My work on anatomy is focused on the lung (Greenbaum and Quirk, 1990: 86).

$$
\begin{aligned}
& \text { 1. يتركز عملي في التشريح على الرئة. } \\
& \text { 2. } \\
& \text { 3. } \\
& \text { 4. } \\
& \text { 5. } \\
& \text { 6. يركز بحثي في علم التثريح على دراسة الرئة. }
\end{aligned}
$$

\begin{tabular}{|c|c|c|c|c|c|c|c|c|c|c|}
\hline \multirow{3}{*}{ Title } & \multirow{4}{*}{ No } & \multicolumn{7}{|c|}{ Reference } & \multicolumn{2}{|c|}{ Trans. } \\
\hline & & \multicolumn{3}{|c|}{ Generic } & \multicolumn{3}{|c|}{ Specific } & \multirow{2}{*}{ Unique } & \multirow{2}{*}{ FE } & \multirow{2}{*}{ DE } \\
\hline & & definite & Indefinite & Zero & definite & Indefinite & Zero & & & \\
\hline $\begin{array}{l}\text { SL Text } \\
\text { English }\end{array}$ & & + & & & & & & & & \\
\hline \multirow{6}{*}{$\begin{array}{c}\text { TL Texts } \\
\text { Arabic }\end{array}$} & 1 & + & & & & & & & + & \\
\hline & 2 & + & & & & & & & + & \\
\hline & 3 & + & & & & & & & + & \\
\hline & 4 & + & & & & & & & + & \\
\hline & 5 & + & & & & & & & + & \\
\hline & 6 & + & & & & & & & + & \\
\hline
\end{tabular}

Text Analysis (5):

The Proposed Rendering:

$$
\text { دراستي في مجال التثريح تنصب بالدرجة الأساس على الرئة. }
$$

6. Marianne plays the harp, frequently accompanied by her brother on the piano. (Greenbaum and Quirk, 1990: 86). 
Text Analysis (6):

\begin{tabular}{|c|c|c|c|c|c|c|c|c|c|c|}
\hline \multirow{3}{*}{ Title } & \multirow{4}{*}{ No } & \multicolumn{7}{|c|}{ Reference } & \multicolumn{2}{|c|}{ Trans. } \\
\hline & & \multicolumn{3}{|c|}{ Generic } & \multicolumn{3}{|c|}{ Specific } & \multirow{2}{*}{ Unique } & \multirow{2}{*}{ FE } & \multirow{2}{*}{ DE } \\
\hline & & definite & Indefinite & Zero & definite & Indefinite & Zero & & & \\
\hline $\begin{array}{l}\text { SL Text } \\
\text { English }\end{array}$ & & + & & & & & & & & \\
\hline \multirow{6}{*}{$\begin{array}{c}\text { TL Texts } \\
\text { Arabic }\end{array}$} & 1 & + & & & & & & & + & \\
\hline & 2 & + & & & & & & & + & \\
\hline & 3 & + & & & & & & & + & \\
\hline & 4 & + & & & & & & & + & \\
\hline & 5 & + & & & & & & & + & \\
\hline & 6 & + & & & & & & & + & \\
\hline
\end{tabular}

\section{The Proposed Rendering:}

تعزف ماريانا القيثارة وغالباً ما يصاحبها أخوها على البيان .

7. Do you remember when everyone was keen on the rumba ? (Greenbaum and Quirk, 1990: 86).

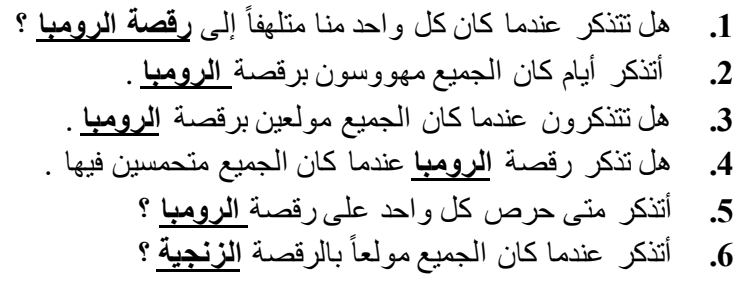

Text Analysis (7):

\begin{tabular}{|c|c|c|c|c|c|c|c|c|c|c|}
\hline \multirow{3}{*}{ Title } & \multirow{4}{*}{ No } & \multicolumn{7}{|c|}{ Reference } & \multicolumn{2}{|c|}{ Trans. } \\
\hline & & \multicolumn{3}{|c|}{ Generic } & \multicolumn{3}{|c|}{ Specific } & \multirow{2}{*}{ Unique } & \multirow{2}{*}{ FE. } & \multirow{2}{*}{ DE } \\
\hline & & definite & Indefinite & Zero & definite & Indefinite & Zero & & & \\
\hline $\begin{array}{l}\text { SL Text } \\
\text { English }\end{array}$ & & + & & & & & & & & \\
\hline & 1 & + & & & & & & & + & \\
\hline
\end{tabular}


TL Texts

Arabic

\begin{tabular}{|c|c|c|c|c|c|}
\hline $\mathbf{2}$ & + & & & & \\
\hline $\mathbf{3}$ & + & & & & \\
\hline $\mathbf{4}$ & + & & & & \\
\hline $\mathbf{5}$ & + & & & & \\
\hline $\mathbf{6}$ & + & & & & \\
\hline
\end{tabular}

The Proposed Rendering:

8. The rich are cooperative people. (personal adjective).

Text Analysis (8):

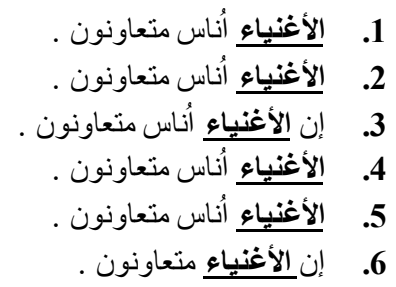

\begin{tabular}{|c|c|c|c|c|c|c|c|c|c|c|}
\hline \multirow{4}{*}{$\begin{array}{c}\text { Title } \\
\\
\text { SL Text } \\
\text { English }\end{array}$} & \multirow{4}{*}{ No } & \multicolumn{7}{|c|}{ Reference } & \multicolumn{2}{|c|}{ Trans. } \\
\hline & & \multicolumn{3}{|c|}{ Generic } & \multicolumn{3}{|c|}{ Specific } & \multirow{2}{*}{ Unique } & \multirow{2}{*}{ FE } & \multirow{2}{*}{ DE } \\
\hline & & definite & Indefinite & Zero & definite & Indefinite & Zero & & & \\
\hline & & + & & & & & & & & \\
\hline \multirow{6}{*}{$\begin{array}{c}\text { TL Texts } \\
\text { Arabic }\end{array}$} & 1 & + & & & & & & & + & \\
\hline & 2 & + & & & & & & & + & \\
\hline & 3 & + & & & & & & & + & \\
\hline & 4 & + & & & & & & & + & \\
\hline & 5 & + & & & & & & & + & \\
\hline & 6 & + & & & & & & & + & \\
\hline
\end{tabular}

The Proposed Rendering:

9. The Germans are good musicians. (Quirk et al, 1985: 265).

الأغنياء أناس متعاونون .

Text Analysis (9):

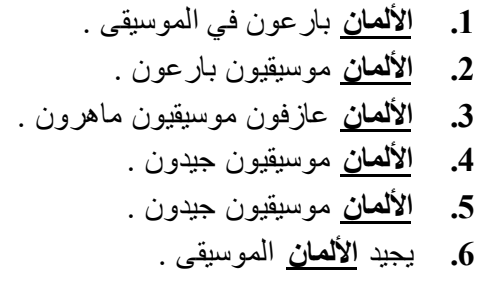

\begin{tabular}{|c|c|c|c|c|c|}
\hline \multirow{2}{*}{ Title } & \multirow{2}{*}{ No } & Generic & Specific & & \\
\cline { 3 - 6 } & & & & \\
\hline
\end{tabular}




\begin{tabular}{|c|c|c|c|c|c|c|c|c|c|c|}
\hline & & definite & Indefinite & Zero & definite & Indefinite & Zero & Unique & FE & $\overline{D E}$ \\
\hline $\begin{array}{l}\text { SL Text } \\
\text { English }\end{array}$ & & + & & & & & & & & \\
\hline \multirow{6}{*}{$\begin{array}{c}\text { TL Texts } \\
\text { Arabic }\end{array}$} & 1 & + & & & & & & & + & \\
\hline & 2 & + & & & & & & & + & \\
\hline & 3 & + & & & & & & & + & \\
\hline & 4 & + & & & & & & & + & \\
\hline & 5 & + & & & & & & & + & \\
\hline & 6 & + & & & & & & & + & \\
\hline
\end{tabular}

The Proposed Rendering:

\subsubsection{Generic Reference / Indefinite:}

1. A bull terrier makes an excellent watchdog. (Quirk et al, 1985: 281).

$$
\begin{aligned}
& \text { 1. } \\
& \text { 2. } \\
& \text { 3. } \\
& \text { 4. } \\
& \text { 5. } \\
& \text { 6. إن كلب البلتريز هو من الكلاب الممتازين للحر اسة . }
\end{aligned}
$$

\begin{tabular}{|c|c|c|c|c|c|c|c|c|c|c|}
\hline \multirow{4}{*}{$\begin{array}{c}\text { Title } \\
\text { SL Text } \\
\text { English }\end{array}$} & \multirow{4}{*}{ No } & \multicolumn{7}{|c|}{ Reference } & \multicolumn{2}{|c|}{ Trans. } \\
\hline & & \multicolumn{3}{|c|}{ Generic } & \multicolumn{3}{|c|}{ Specific } & \multirow{2}{*}{ Unique } & \multirow{2}{*}{ FE. } & \multirow{2}{*}{ DE } \\
\hline & & definite & Indefinite & Zero & definite & Indefinite & Zero & & & \\
\hline & & & + & & & & & & & \\
\hline \multirow{6}{*}{$\begin{array}{c}\text { TL Texts } \\
\text { Arabic }\end{array}$} & 1 & + & & & & & & & & + \\
\hline & 2 & + & & & & & & & & + \\
\hline & 3 & + & & & & & & & & + \\
\hline & 4 & + & & & & & & & & + \\
\hline & 5 & + & & & & & & & & + \\
\hline & 6 & + & & & & & & & & + \\
\hline
\end{tabular}

Text Analysis (1):

The Proposed Rendering:

$$
\text { كلب التريز هو من أروع كلب من كلاب الحراسة. }
$$

2. The best way to learn a language is to live among its speakers. (Quirk et al, 1985: 281). 
Text Analysis (2):

\begin{tabular}{|c|c|c|c|c|c|c|c|c|c|c|}
\hline \multirow{3}{*}{ Title } & \multirow{4}{*}{ No } & \multicolumn{7}{|c|}{ Reference } & \multicolumn{2}{|c|}{ Trans. } \\
\hline & & \multicolumn{3}{|c|}{ Generic } & \multicolumn{3}{|c|}{ Specific } & \multirow{2}{*}{ Unique } & \multirow{2}{*}{ FE. } & \multirow{2}{*}{ DE } \\
\hline & & definite & Indefinite & Zero & definite & Indefinite & Zero & & & \\
\hline $\begin{array}{l}\text { SL Text } \\
\text { English }\end{array}$ & & & + & & & & & & + & \\
\hline \multirow{6}{*}{$\begin{array}{c}\text { TL Texts } \\
\text { Arabic }\end{array}$} & 1 & + & & & & & & & & + \\
\hline & 2 & & + & & & & & & + & \\
\hline & 3 & + & & & & & & & & + \\
\hline & 4 & & + & & & & & & + & \\
\hline & 5 & + & & & & & & & & + \\
\hline & 6 & & + & & & & & & + & \\
\hline
\end{tabular}

The Proposed Rendering:

3. A Tiger can be dangerous. (Quirk et al, 1985: 265).

أفضل وسيلة لتعلم اللغة هي العيش مع متحدثيها .

1

2.

3.

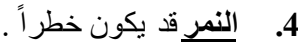

5.

6. النمر حيو ان خطير ل.

Text Analysis (3):

\begin{tabular}{|c|c|c|c|c|c|c|c|c|c|c|}
\hline \multirow{4}{*}{$\begin{array}{c}\text { Title } \\
\\
\text { SL Text } \\
\text { English }\end{array}$} & \multirow{4}{*}{ No } & \multicolumn{7}{|c|}{ Reference } & \multicolumn{2}{|c|}{ Trans. } \\
\hline & & \multicolumn{3}{|c|}{ Generic } & \multicolumn{3}{|c|}{ Specific } & \multirow{2}{*}{ Unique } & \multirow{2}{*}{ FE } & \multirow{2}{*}{ DE } \\
\hline & & definite & Indefinite & Zero & definite & Indefinite & Zero & & & \\
\hline & & & + & & & & & & & \\
\hline \multirow{6}{*}{$\begin{array}{c}\text { TL Texts } \\
\text { Arabic }\end{array}$} & 1 & + & & & & & & & & + \\
\hline & 2 & + & & & & & & & & + \\
\hline & 3 & + & & & & & & & & + \\
\hline & 4 & + & & & & & & & & + \\
\hline & 5 & + & & & & & & & & + \\
\hline & 6 & + & & & & & & & & + \\
\hline
\end{tabular}

The Proposed Rendering:

قد يكون النمر خطير اً . 
4. Leonard wants to marry a princess who speaks five languages. (Quirk et al, 1985: 273).

Text Analysis (4):

$$
\begin{aligned}
& \text { 1 } \\
& \text { 2. }
\end{aligned}
$$

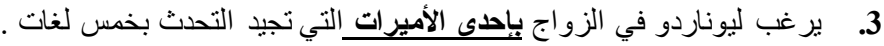

$$
\begin{aligned}
& \text { 4. } \\
& \text { 5. }
\end{aligned}
$$

\begin{tabular}{|c|c|c|c|c|c|c|c|c|c|c|}
\hline \multirow{3}{*}{ Title } & \multirow{4}{*}{ No } & \multicolumn{7}{|c|}{ Reference } & \multicolumn{2}{|c|}{ Trans. } \\
\hline & & \multicolumn{3}{|c|}{ Generic } & \multicolumn{3}{|c|}{ Specific } & \multirow{2}{*}{ Unique } & \multirow{2}{*}{ FE. } & \multirow{2}{*}{ DE } \\
\hline & & definite & Indefinite & Zero & definite & Indefinite & Zero & & & \\
\hline $\begin{array}{l}\text { SL Text } \\
\text { English }\end{array}$ & & & + & & & & & & & \\
\hline \multirow{6}{*}{$\begin{array}{c}\text { TL Texts } \\
\text { Arabic }\end{array}$} & 1 & & + & & & & & & + & \\
\hline & 2 & & + & & & & & & + & \\
\hline & 3 & + & & & & & & & & + \\
\hline & 4 & & + & & & & & & + & \\
\hline & 5 & & + & & & & & & + & \\
\hline & 6 & & + & & & & & & + & \\
\hline
\end{tabular}

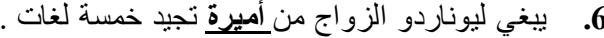

\section{The Proposed Rendering:}

$$
\text { يريد ليوناردو أن يتزوج من أميرة تجيد التحدث بخمس لغات . }
$$

5. If one wants to buy a used car, he has to open the hood at least once.

(Yeom, 1998: 98).

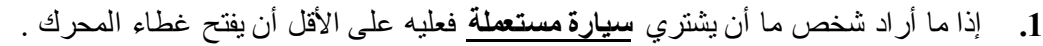
2.

3.

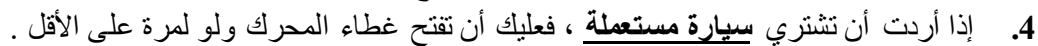

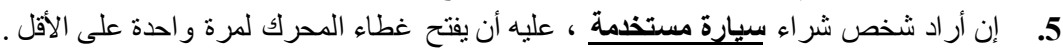

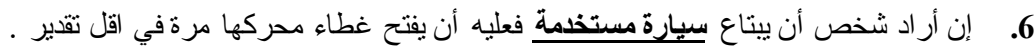

Text Analysis (5):

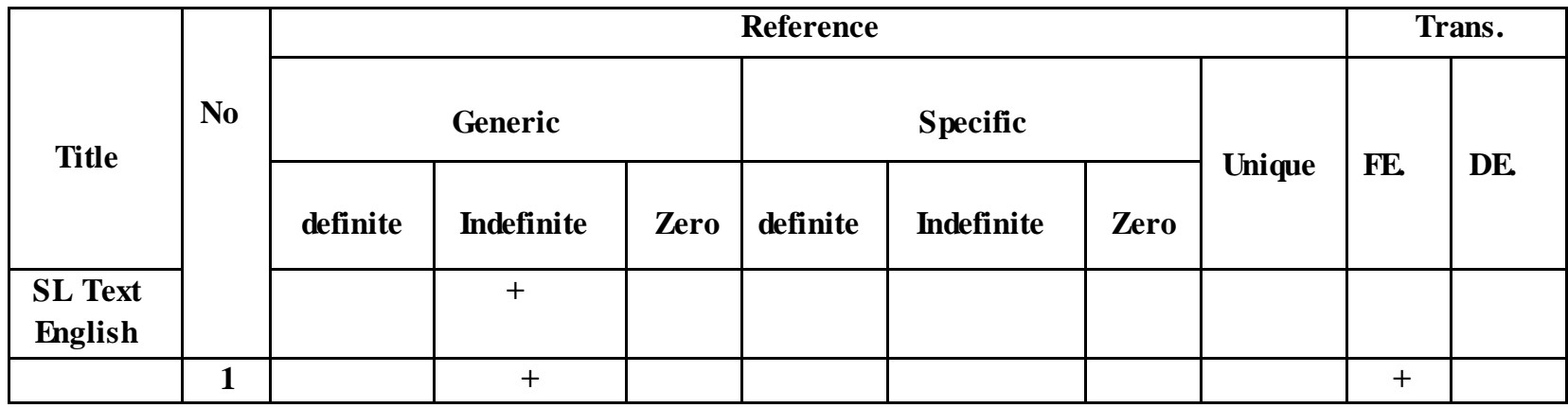


TL Texts Arabic

\begin{tabular}{|l|l|r|}
\hline $\mathbf{2}$ & & + \\
\hline $\mathbf{3}$ & & + \\
\hline $\mathbf{4}$ & & + \\
\hline $\mathbf{5}$ & & + \\
\hline $\mathbf{6}$ & & + \\
\hline
\end{tabular}

The Proposed Rendering:

\begin{tabular}{|c|l|l|l|l|l|l|l|}
\hline+ & & & & & & + & \\
\hline+ & & & & & & + & \\
\hline+ & & & & & & + & \\
\hline+ & & & & & & + & \\
\hline+ & & & & & & + & \\
\hline
\end{tabular}

إذا أراد احد أن يشتري سيارة مستعملة فعليه أن يقتح غطاء محركها لمرة واحدة على الأقل .

6. Travelling by an aeroplane is more comfortable than a car. (Yeom, 1998: 99).

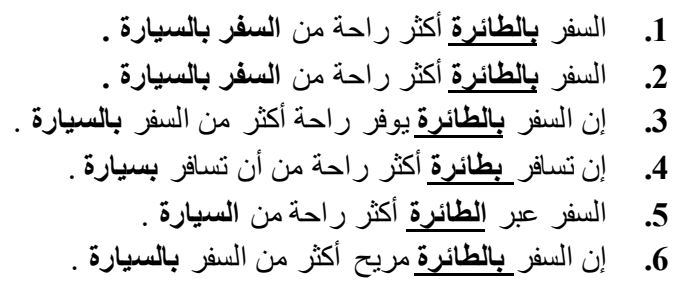

Text Analysis (6):

\begin{tabular}{|c|c|c|c|c|c|c|c|c|c|c|}
\hline \multirow{3}{*}{ Title } & \multirow{4}{*}{ No } & \multicolumn{7}{|c|}{ Reference } & \multicolumn{2}{|c|}{ Trans. } \\
\hline & & \multicolumn{3}{|c|}{ Generic } & \multicolumn{3}{|c|}{ Specific } & \multirow{2}{*}{ Unique } & \multirow[b]{2}{*}{ FE } & \multirow[b]{2}{*}{ DE } \\
\hline & & definite & Indefinite & Zero & definite & Indefinite & Zero & & & \\
\hline $\begin{array}{l}\text { SL Text } \\
\text { English }\end{array}$ & & & + & & & & & & & \\
\hline \multirow{6}{*}{$\begin{array}{c}\text { TL Texts } \\
\text { Arabic }\end{array}$} & 1 & + & & & & & & & & + \\
\hline & 2 & + & & & & & & & & + \\
\hline & 3 & + & & & & & & & & + \\
\hline & 4 & & + & & & & & & + & \\
\hline & 5 & + & & & & & & & & + \\
\hline & 6 & + & & & & & & & & + \\
\hline
\end{tabular}

The Proposed Rendering:

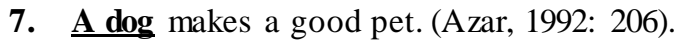

السفر بالطائرة أكثر راحة من السفر بالسيارة .

A dog makes a good pet. (Azar, 1992: 206).
1.
2.
3.

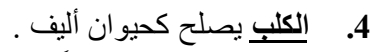

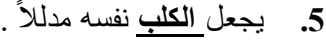
6. يمكن استأناس الكلب .

Text Analysis (7):

\begin{tabular}{|c|c|c|c|c|c|c|}
\hline \multirow{3}{*}{ Title } & \multirow{3}{*}{} & \multirow{3}{*}{ Generic } & Reference & & & \\
\cline { 3 - 7 } & No & Specific & Unique & FE & DE. \\
\hline
\end{tabular}




\begin{tabular}{|c|c|c|c|c|c|c|c|c|}
\hline & & definite & Indefinite & Zero & definite & Indefinite & Zero & \\
\hline $\begin{array}{l}\text { SL Text } \\
\text { English }\end{array}$ & & & + & & & & & \\
\hline \multirow{6}{*}{$\begin{array}{c}\text { TL Texts } \\
\text { Arabic }\end{array}$} & 1 & + & & & & & & + \\
\hline & 2 & + & & & & & & + \\
\hline & 3 & + & & & & & & + \\
\hline & 4 & + & & & & & & + \\
\hline & 5 & + & & & & & & + \\
\hline & 6 & + & & & & & & + \\
\hline
\end{tabular}

The Proposed Rendering:

8. A Pencil contains lead. (Azar, 1992: 206).

Text Analysis (8):

\begin{tabular}{|c|c|c|c|c|c|c|c|c|c|c|}
\hline \multirow{3}{*}{ Title } & \multirow{4}{*}{ No } & \multicolumn{7}{|c|}{ Reference } & \multicolumn{2}{|c|}{ Trans. } \\
\hline & & \multicolumn{3}{|c|}{ Generic } & \multicolumn{3}{|c|}{ Specific } & \multirow{2}{*}{ Unique } & \multirow{2}{*}{ FE. } & \multirow{2}{*}{ DE } \\
\hline & & definite & Indefinite & Zero & definite & Indefinite & Zero & & & \\
\hline $\begin{array}{l}\text { SL Text } \\
\text { English }\end{array}$ & & & + & & & & & & & \\
\hline \multirow{6}{*}{$\begin{array}{c}\text { TL Texts } \\
\text { Arabic }\end{array}$} & 1 & + & & & & & & & & + \\
\hline & 2 & + & & & & & & & & + \\
\hline & 3 & + & & & & & & & & + \\
\hline & 4 & + & & & & & & & & + \\
\hline & 5 & + & & & & & & & & + \\
\hline & 6 & + & & & & & & & & + \\
\hline
\end{tabular}

The Proposed Rendering:

3.3.3. Generic Reference / Zero " $\varnothing$ " or "some":

1. I want some bread, please. (Quirk et al, 1985: 265). 
Text Analysis (1):

\begin{tabular}{|c|c|c|c|c|c|c|c|c|c|c|}
\hline \multirow{3}{*}{ Title } & \multirow{4}{*}{ No } & \multicolumn{7}{|c|}{ Reference } & \multicolumn{2}{|c|}{ Trans. } \\
\hline & & \multicolumn{3}{|c|}{ Generic } & \multicolumn{3}{|c|}{ Specific } & \multirow{2}{*}{ Unique } & \multirow{2}{*}{ FE. } & \multirow{2}{*}{ DE } \\
\hline & & definite & Indefinite & Zero & definite & Indefinite & Zero & & & \\
\hline $\begin{array}{l}\text { SL Text } \\
\text { English }\end{array}$ & & & & + & & & & & & \\
\hline \multirow{6}{*}{$\begin{array}{c}\text { TL Texts } \\
\text { Arabic }\end{array}$} & 1 & + & & & & & & & & + \\
\hline & 2 & + & & & & & & & & + \\
\hline & 3 & + & & & & & & & & + \\
\hline & 4 & + & & & & & & & & + \\
\hline & 5 & + & & & & & & & & + \\
\hline & 6 & + & & & & & & & & + \\
\hline
\end{tabular}

\section{The Proposed Rendering:}

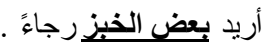

2. Milk is good for you. (Quirk et al, 1985: 274).

$$
\begin{aligned}
& \text { 1. الحليب جيد لصحتلك . } \\
& \text { 2. } \\
& \text { 3. } \\
& \text { 4. } \\
& \text { 5. } \\
& \text { 6. }
\end{aligned}
$$

\begin{tabular}{|c|c|c|c|c|c|c|c|c|c|c|}
\hline \multirow{3}{*}{ Title } & \multirow{4}{*}{ No } & \multicolumn{7}{|c|}{ Reference } & \multicolumn{2}{|c|}{ Trans. } \\
\hline & & \multicolumn{3}{|c|}{ Generic } & \multicolumn{3}{|c|}{ Specific } & \multirow[b]{2}{*}{ Unique } & \multirow[b]{2}{*}{ FE. } & \multirow[b]{2}{*}{ DE } \\
\hline & & definite & Indefinite & Zero & definite & Indefinite & Zero & & & \\
\hline $\begin{array}{l}\text { SL Text } \\
\text { English }\end{array}$ & & & & + & & & & & & \\
\hline \multirow{6}{*}{$\begin{array}{c}\text { TL Texts } \\
\text { Arabic }\end{array}$} & 1 & + & & & & & & & & + \\
\hline & 2 & + & & & & & & & & + \\
\hline & 3 & + & & & & & & & & + \\
\hline & 4 & + & & & & & & & & + \\
\hline & 5 & + & & & & & & & & + \\
\hline & 6 & + & & & & & & & & + \\
\hline
\end{tabular}

Text Analysis (2):

\section{The Proposed Rendering:}

3. I have just bought some melons. (Quirk et al, 1985: 274). 
Text Analysis (3):

\begin{tabular}{|c|c|c|c|c|c|c|c|c|c|c|}
\hline \multirow{3}{*}{ Title } & \multirow{4}{*}{ No } & \multicolumn{7}{|c|}{ Reference } & \multicolumn{2}{|c|}{ Trans. } \\
\hline & & \multicolumn{3}{|c|}{ Generic } & \multicolumn{3}{|c|}{ Specific } & \multirow[t]{2}{*}{ Unique } & \multirow[t]{2}{*}{ FE. } & \multirow[t]{2}{*}{ DE } \\
\hline & & definite & Indefinite & Zero & definite & Indefinite & Zero & & & \\
\hline $\begin{array}{l}\text { SL Text } \\
\text { English }\end{array}$ & & & & + & & & & & & \\
\hline \multirow{6}{*}{$\begin{array}{c}\text { TL Texts } \\
\text { Arabic }\end{array}$} & 1 & + & & & & & & & & + \\
\hline & 2 & + & & & & & & & & + \\
\hline & 3 & + & & & & & & & & + \\
\hline & 4 & & + & & & & & & & + \\
\hline & 5 & + & & & & & & & & + \\
\hline & 6 & + & & & & & & & & + \\
\hline
\end{tabular}

The Proposed Rendering:

$$
\text { لقد اشتريت بعض البطيخ نواً. }
$$

4. Joe has been chasing women ever since he was young. (Quirk et al, 1985: 275).

$$
\begin{aligned}
& \text { 1 . كان جوي مغرماً بملاحقة النساءع منذ أن كان شاباً . }
\end{aligned}
$$

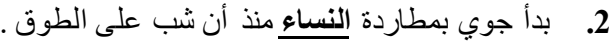

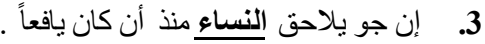

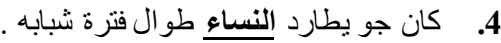

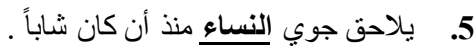

$$
\begin{aligned}
& \text { 6. بلاحق جو النساءع منذ شبابه . }
\end{aligned}
$$

\begin{tabular}{|c|c|c|c|c|c|c|c|c|c|c|}
\hline \multirow{3}{*}{ Title } & \multirow{4}{*}{ No } & \multicolumn{7}{|c|}{ Reference } & \multicolumn{2}{|c|}{ Trans. } \\
\hline & & \multicolumn{3}{|c|}{ Generic } & \multicolumn{3}{|c|}{ Specific } & \multirow{2}{*}{ Unique } & \multirow{2}{*}{ FE. } & \\
\hline & & definite & Indefinite & Zero & definite & Indefinite & Zero & & & \\
\hline $\begin{array}{l}\text { SL Text } \\
\text { English }\end{array}$ & & & & + & & & & & & \\
\hline \multirow{6}{*}{$\begin{array}{c}\text { TL Texts } \\
\text { Arabic }\end{array}$} & 1 & + & & & & & & & & + \\
\hline & 2 & + & & & & & & & & + \\
\hline & 3 & + & & & & & & & & + \\
\hline & 4 & + & & & & & & & & + \\
\hline & 5 & + & & & & & & & & + \\
\hline & 6 & + & & & & & & & & + \\
\hline
\end{tabular}

Text Analysis (4):

\section{The Proposed Rendering:}

5. Cigarettes are bad for our health. (Quirk et al, 1985: 282).

يلاحق جو النساع منذ أن كان شاباً.

1 
Text Analysis (5):

\begin{tabular}{|c|c|c|c|c|c|c|c|c|c|c|}
\hline \multirow{3}{*}{ Title } & \multirow{4}{*}{ No } & \multicolumn{7}{|c|}{ Reference } & \multicolumn{2}{|c|}{ Trans. } \\
\hline & & \multicolumn{3}{|c|}{ Generic } & \multicolumn{3}{|c|}{ Specific } & \multirow[b]{2}{*}{ Unique } & \multirow[b]{2}{*}{ FE. } & \multirow[b]{2}{*}{ DE } \\
\hline & & definite & Indefinite & Zero & definite & Indefinite & Zero & & & \\
\hline $\begin{array}{l}\text { SL Text } \\
\text { English }\end{array}$ & & & & + & & & & & & \\
\hline \multirow{6}{*}{$\begin{array}{c}\text { TL Texts } \\
\text { Arabic }\end{array}$} & 1 & + & & & & & & & & + \\
\hline & 2 & + & & & & & & & & + \\
\hline & 3 & + & & & & & & & & + \\
\hline & 4 & + & & & & & & & & + \\
\hline & 5 & + & & & & & & & & + \\
\hline & 6 & + & & & & & & & & + \\
\hline
\end{tabular}

The Proposed Rendering:

6. Hunger and violence will continue to mark the future of mankind. (Quirk et al, 1985: 282).

السكائر ضارة بصحتنا .

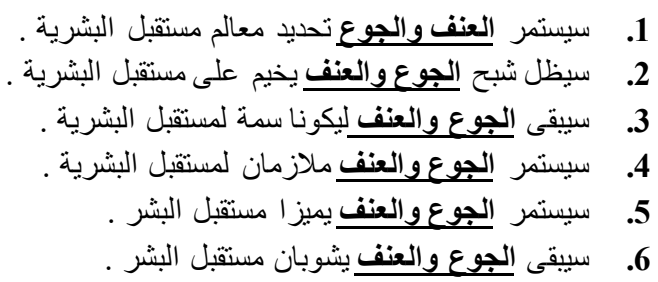

Text Analysis (6):

\begin{tabular}{|c|c|c|c|c|c|c|c|c|c|c|}
\hline \multirow{3}{*}{ Title } & \multirow{4}{*}{ No } & \multicolumn{7}{|c|}{ Reference } & \multicolumn{2}{|c|}{ Trans. } \\
\hline & & \multicolumn{3}{|c|}{ Generic } & \multicolumn{3}{|c|}{ Specific } & \multirow{2}{*}{ Unique } & \multirow{2}{*}{ FE } & \multirow{2}{*}{ DE } \\
\hline & & definite & Indefinite & Zero & definite & Indefinite & Zero & & & \\
\hline $\begin{array}{l}\text { SL Text } \\
\text { English }\end{array}$ & & & & + & & & & & & \\
\hline \multirow{6}{*}{$\begin{array}{c}\text { TL Texts } \\
\text { Arabic }\end{array}$} & 1 & + & & & & & & & & + \\
\hline & 2 & + & & & & & & & & + \\
\hline & 3 & + & & & & & & & & + \\
\hline & 4 & + & & & & & & & & + \\
\hline & 5 & + & & & & & & & & + \\
\hline & 6 & + & & & & & & & & + \\
\hline
\end{tabular}


The Proposed Rendering:

7. John likes music. (Quirk et al, 1972: 153).

$$
\text { سيظل شبح الجوع والعنف يخيم على مستقبل البشرية . }
$$

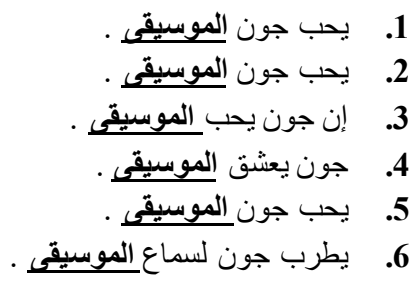

Text Analysis (7):

\begin{tabular}{|c|c|c|c|c|c|c|c|c|c|c|}
\hline \multirow{4}{*}{$\begin{array}{c}\text { Title } \\
\\
\text { SL Text } \\
\text { English }\end{array}$} & \multirow{4}{*}{ No } & \multicolumn{7}{|c|}{ Reference } & \multicolumn{2}{|c|}{ Trans. } \\
\hline & & \multicolumn{3}{|c|}{ Generic } & \multicolumn{3}{|c|}{ Specific } & \multirow{2}{*}{ Unique } & \multirow{2}{*}{ FE. } & \multirow{2}{*}{ DE } \\
\hline & & definite & Indefinite & Zero & definite & Indefinite & Zero & & & \\
\hline & & & & + & & & & & & \\
\hline \multirow{6}{*}{$\begin{array}{c}\text { TL Texts } \\
\text { Arabic }\end{array}$} & 1 & + & & & & & & & & + \\
\hline & 2 & + & & & & & & & & + \\
\hline & 3 & + & & & & & & & & + \\
\hline & 4 & + & & & & & & & & + \\
\hline & 5 & + & & & & & & & & + \\
\hline & 6 & + & & & & & & & & + \\
\hline
\end{tabular}

The Proposed Rendering:

يحب جون الموسيقى .

8. Appearances can be deceptive. (Quirk et al, 1972: 153).

$$
\begin{aligned}
& \text { 1. قد تكون المظاهر خداعة . } \\
& \text { 2. } \\
& \text { 3. المظاهر قد تكون خداعة . } \\
& \text { 4. المظاهر خداعة . } \\
& \text { 5. }
\end{aligned}
$$

\begin{tabular}{|c|c|c|c|c|c|c|c|c|c|c|}
\hline \multirow{3}{*}{ Title } & \multirow{4}{*}{ No } & \multicolumn{7}{|c|}{ Reference } & \multicolumn{2}{|c|}{ Trans. } \\
\hline & & \multicolumn{3}{|c|}{ Generic } & \multicolumn{3}{|c|}{ Specific } & \multirow{2}{*}{ Unique } & \multirow{2}{*}{ FE. } & \multirow{2}{*}{ DE } \\
\hline & & definite & Indefinite & Zero & definite & Indefinite & Zero & & & \\
\hline SL Text & & & & + & & & & & & \\
\hline
\end{tabular}

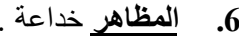

Text Analysis (8): 


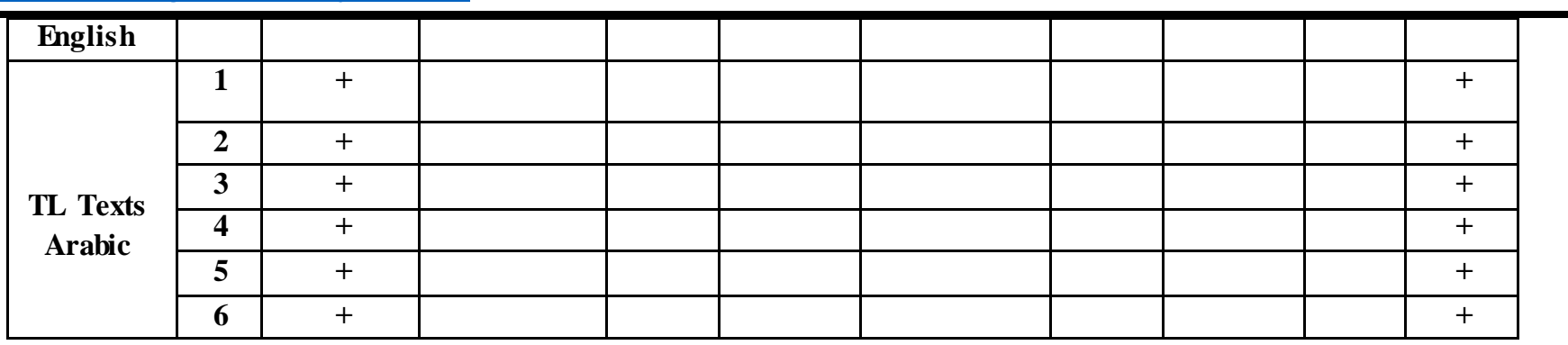

The Proposed Rendering:

$$
\text { قد تكون المظاهر خداعة . }
$$

9. Happiness is often the product of honesty and hard work. (Quirk et al, 1985: 286).

$$
\begin{aligned}
& \text { 1 } \\
& \text { 2. }
\end{aligned}
$$

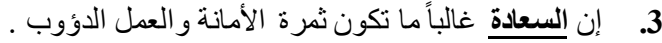

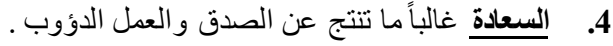

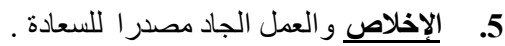

\begin{tabular}{|c|c|c|c|c|c|c|c|c|c|c|}
\hline \multirow{3}{*}{ Title } & \multirow{4}{*}{ No } & \multicolumn{7}{|c|}{ Reference } & \multicolumn{2}{|c|}{ Trans. } \\
\hline & & \multicolumn{3}{|c|}{ Generic } & \multicolumn{3}{|c|}{ Specific } & \multirow{2}{*}{ Unique } & \multirow{2}{*}{ FE } & \multirow{2}{*}{ DE. } \\
\hline & & definite & Indefinite & Zero & definite & Indefinite & Zero & & & \\
\hline $\begin{array}{l}\text { SL Text } \\
\text { English }\end{array}$ & & & & + & & & & & & \\
\hline \multirow{6}{*}{$\begin{array}{c}\text { TL Texts } \\
\text { Arabic }\end{array}$} & 1 & + & & & & & & & & + \\
\hline & 2 & + & & & & & & & & + \\
\hline & 3 & + & & & & & & & & + \\
\hline & 4 & + & & & & & & & & + \\
\hline & 5 & + & & & & & & & & + \\
\hline & 6 & + & & & & & & & & + \\
\hline
\end{tabular}

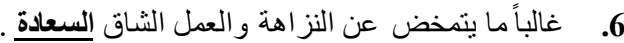

Text Analysis (9):

The Proposed Rendering:

10. Welshmen are fond of singing. (Quirk et al, 1985: 284).

$$
\text { السعادة في الغالب ثمرة النزاهة و العمل الدؤوب . }
$$

$$
\begin{aligned}
& \text { 1. أهل وينز مولعون بالغناء . } \\
& \text { 2. } \\
& \text { 3. الويلزيون مولعون بالغناء . }
\end{aligned}
$$

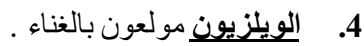

$$
\begin{aligned}
& \text { 5. الويلزيون مغرمون بالغناء . }
\end{aligned}
$$

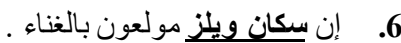

Text Analysis (10):

\begin{tabular}{|l|l|ll|l|}
\hline & Reference & Trans. \\
\hline
\end{tabular}




\begin{tabular}{|c|c|c|c|c|c|c|c|c|c|c|}
\hline \multirow{2}{*}{ Title } & \multirow{3}{*}{ No } & \multicolumn{3}{|c|}{ Generic } & \multicolumn{3}{|c|}{ Specific } & \multirow{2}{*}{ Unique } & \multirow{2}{*}{ FE. } & \multirow{2}{*}{ DE. } \\
\hline & & definite & Indefinite & Zero & definite & Indefinite & Zero & & & \\
\hline $\begin{array}{l}\text { SL Text } \\
\text { English }\end{array}$ & & & & + & & & & & & \\
\hline \multirow{6}{*}{$\begin{array}{c}\text { TL Texts } \\
\text { Arabic }\end{array}$} & 1 & + & & & & & & & & + \\
\hline & 2 & + & & & & & & & & + \\
\hline & 3 & + & & & & & & & & + \\
\hline & 4 & + & & & & & & & & + \\
\hline & 5 & + & & & & & & & & + \\
\hline & 6 & + & & & & & & & & + \\
\hline
\end{tabular}

The Proposed Rendering:

11. Butter is a dairy product. (Azar, 1992: 212).

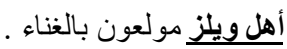

Text Analysis (11):

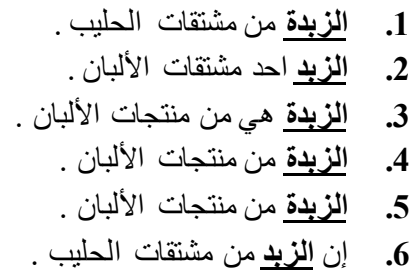

\begin{tabular}{|c|c|c|c|c|c|c|c|c|c|c|}
\hline \multirow{3}{*}{ Title } & \multirow{4}{*}{ No } & \multicolumn{7}{|c|}{ Reference } & \multicolumn{2}{|c|}{ Trans. } \\
\hline & & \multicolumn{3}{|c|}{ Generic } & \multicolumn{3}{|c|}{ Specific } & \multirow[b]{2}{*}{ Unique } & \multirow[b]{2}{*}{ FE. } & \multirow[b]{2}{*}{ DE } \\
\hline & & definite & Indefinite & Zero & definite & Indefinite & Zero & & & \\
\hline $\begin{array}{l}\text { SL Text } \\
\text { English }\end{array}$ & & & & + & & & & & & \\
\hline \multirow{6}{*}{$\begin{array}{c}\text { TL Texts } \\
\text { Arabic }\end{array}$} & 1 & + & & & & & & & + & \\
\hline & 2 & + & & & & & & & + & \\
\hline & 3 & + & & & & & & & + & \\
\hline & 4 & + & & & & & & & + & \\
\hline & 5 & + & & & & & & & + & \\
\hline & 6 & + & & & & & & & + & \\
\hline
\end{tabular}

The Proposed Rendering:

3.3.4. Specific Reference / Definite:

الزبد احد مشتقات الألبان .

1. The Finns I know are fond of sports. (Quirk et al, 1985: 284).

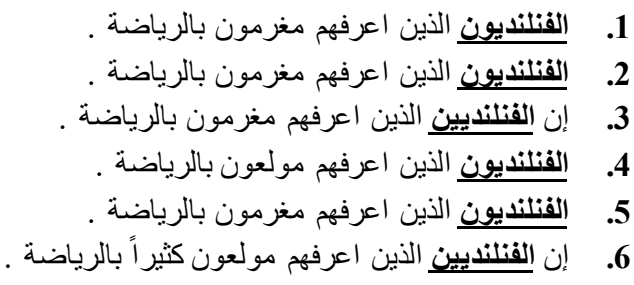


Text Analysis (1):

\begin{tabular}{|c|c|c|c|c|c|c|c|c|c|c|}
\hline \multirow{3}{*}{ Title } & \multirow{4}{*}{ No } & \multicolumn{7}{|c|}{ Reference } & \multicolumn{2}{|c|}{ Trans. } \\
\hline & & \multicolumn{3}{|c|}{ Generic } & \multicolumn{3}{|c|}{ Specific } & \multirow[b]{2}{*}{ Unique } & \multirow[b]{2}{*}{ FE } & \multirow[b]{2}{*}{ DE } \\
\hline & & definite & Indefinite & Zero & definite & Indefinite & Zero & & & \\
\hline $\begin{array}{l}\text { SL Text } \\
\text { English }\end{array}$ & & & & & + & & & & & \\
\hline \multirow{6}{*}{$\begin{array}{c}\text { TL Texts } \\
\text { Arabic }\end{array}$} & 1 & & & & + & & & & + & \\
\hline & 2 & & & & + & & & & + & \\
\hline & 3 & & & & + & & & & + & \\
\hline & 4 & & & & + & & & & + & \\
\hline & 5 & & & & + & & & & + & \\
\hline & 6 & & & & + & & & & + & \\
\hline
\end{tabular}

\section{The Proposed Rendering:}

الفنلنديون الذين اعرفهم مغرمون بالرياضة .

2. The king of France does not exist. (Yeom, 1998: 99).

1. لا يوجد ملك على عرش فرنسا. 2.

3.

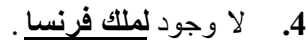

6

6. لا يوجد ملك على في فرنسيا.

Text Analysis (2):

\begin{tabular}{|c|c|c|c|c|c|c|c|c|c|c|}
\hline \multirow{4}{*}{$\begin{array}{c}\text { Title } \\
\text { SL Text } \\
\text { English } \\
\end{array}$} & \multirow{4}{*}{ No } & \multicolumn{7}{|c|}{ Reference } & \multicolumn{2}{|c|}{ Trans. } \\
\hline & & \multicolumn{3}{|c|}{ Generic } & \multicolumn{3}{|c|}{ Specific } & \multirow[b]{2}{*}{ Unique } & \multirow[b]{2}{*}{ FE. } & \multirow[b]{2}{*}{ DE } \\
\hline & & definite & Indefinite & Zero & definite & Indefinite & Zero & & & \\
\hline & & & & & + & & & & & \\
\hline \multirow{6}{*}{$\begin{array}{c}\text { TL Texts } \\
\text { Arabic }\end{array}$} & 1 & & & & & & + & & & + \\
\hline & 2 & & & & + & & & & + & \\
\hline & 3 & & & & + & & & & + & \\
\hline & 4 & & & & + & & & & + & \\
\hline & 5 & & & & + & & & & + & \\
\hline & 6 & & & & & & + & & & + \\
\hline
\end{tabular}

The Proposed Rendering:

لا وجود لملثك فرنسيا على ارض الواقع.

3. She is studying the history of Europe. (Quirk et al, 1985: 286).

1

2.

3.

4. 
Text Analysis (3):

\begin{tabular}{|c|c|c|c|c|c|c|c|c|c|c|}
\hline \multirow[b]{3}{*}{ Title } & \multirow{4}{*}{ No } & \multicolumn{7}{|c|}{ Reference } & \multicolumn{2}{|c|}{ Trans. } \\
\hline & & \multicolumn{3}{|c|}{ Generic } & \multicolumn{3}{|c|}{ Specific } & \multirow[b]{2}{*}{ Unique } & \multirow[b]{2}{*}{ FE } & \multirow[b]{2}{*}{ DE } \\
\hline & & definite & Indefinite & Zero & definite & Indefinite & Zero & & & \\
\hline $\begin{array}{l}\text { SL Text } \\
\text { English }\end{array}$ & & & & & + & & & & & \\
\hline \multirow{6}{*}{$\begin{array}{c}\text { TL Texts } \\
\text { Arabic }\end{array}$} & 1 & & & & + & & & & + & \\
\hline & 2 & & & & + & & & & + & \\
\hline & 3 & & & & + & & & & + & \\
\hline & 4 & & & & + & & & & + & \\
\hline & 5 & & & & + & & & & + & \\
\hline & 6 & & & & + & & & & + & \\
\hline
\end{tabular}

The Proposed Rendering:

4. The Germans in this company are hard working. (Yeom, 1998: 99).

Text Analysis (4):

\begin{tabular}{|c|c|c|c|c|c|c|c|c|c|c|}
\hline \multirow{3}{*}{ Title } & \multirow{4}{*}{ No } & \multicolumn{7}{|c|}{ Reference } & \multicolumn{2}{|c|}{ Trans. } \\
\hline & & \multicolumn{3}{|c|}{ Generic } & \multicolumn{3}{|c|}{ Specific } & \multirow{2}{*}{ Unique } & \multirow{2}{*}{ FE } & \multirow{2}{*}{ DE } \\
\hline & & definite & Indefinite & Zero & definite & Indefinite & Zero & & & \\
\hline $\begin{array}{l}\text { SL Text } \\
\text { English }\end{array}$ & & & & & + & & & & & \\
\hline \multirow{6}{*}{$\begin{array}{c}\text { TL Texts } \\
\text { Arabic }\end{array}$} & $\overline{1}$ & & & & + & & & & t & \\
\hline & 2 & & & & + & & & & t & \\
\hline & 3 & & & & + & & & & + & \\
\hline & 4 & & & & + & & & & + & \\
\hline & 5 & & & & + & & & & + & \\
\hline & 6 & & & & + & & & & t & \\
\hline
\end{tabular}

\section{The Proposed Rendering:}

$$
\text { الألمان العاملون في هذه الثركة مجدون . }
$$

5. The house on the hill belongs to a rich merchant. (Yeom, 1998: 102).

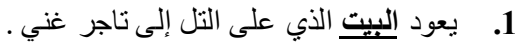


Text Analysis (5):

\begin{tabular}{|c|c|c|c|c|c|c|c|c|c|c|}
\hline \multirow{3}{*}{ Title } & \multirow{4}{*}{ No } & \multicolumn{7}{|c|}{ Reference } & \multicolumn{2}{|c|}{ Trans. } \\
\hline & & \multicolumn{3}{|c|}{ Generic } & \multicolumn{3}{|c|}{ Specific } & \multirow{2}{*}{ Unique } & \multirow{2}{*}{ FE } & \multirow{2}{*}{ DE } \\
\hline & & definite & Indefinite & Zero & definite & Indefinite & Zero & & & \\
\hline $\begin{array}{l}\text { SL Text } \\
\text { English }\end{array}$ & & & & & + & & & & & \\
\hline \multirow{6}{*}{$\begin{array}{c}\text { TL Texts } \\
\text { Arabic }\end{array}$} & 1 & & & & + & & & & + & \\
\hline & 2 & & & & + & & & & + & \\
\hline & 3 & & & & + & & & & + & \\
\hline & 4 & & & & + & & & & + & \\
\hline & 5 & & & & + & & & & + & \\
\hline & 6 & & & & + & & & & + & \\
\hline
\end{tabular}

The Proposed Rendering:

تعود ملكية المنزل الذي يقع على التل إلى احد التجار الأغنياء .

6. The man who is sitting in the front row will be the main speaker (Yome, 1998: 102).

1. سيكون الرجل الجالس في الصف الأمامي الرتحدث الرئيسي . 2. 3. 4.

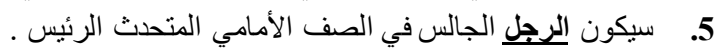

6. سيكون الرجل الجالس في الصف الأمامي المنحدث الرئيس .

Text Analysis (6):

\begin{tabular}{|c|c|c|c|c|c|c|c|c|c|c|}
\hline \multirow{3}{*}{ Title } & \multirow{4}{*}{ No } & \multicolumn{7}{|c|}{ Reference } & \multicolumn{2}{|c|}{ Trans. } \\
\hline & & \multicolumn{3}{|c|}{ Generic } & \multicolumn{3}{|c|}{ Specific } & \multirow{2}{*}{ Unique } & \multirow{2}{*}{ FE } & \multirow{2}{*}{ DE. } \\
\hline & & definite & Indefinite & Zero & definite & Indefinite & Zero & & & \\
\hline $\begin{array}{l}\text { SL Text } \\
\text { English }\end{array}$ & & & & & + & & & & & \\
\hline \multirow{5}{*}{$\begin{array}{c}\text { TL Texts } \\
\text { Arabic }\end{array}$} & 1 & & & & + & & & & + & \\
\hline & 2 & & & & + & & & & + & \\
\hline & 3 & & & & + & & & & + & \\
\hline & 4 & & & & + & & & & + & \\
\hline & 5 & & & & + & & & & + & \\
\hline
\end{tabular}


The Proposed Rendering:

7. Georgia is the Elizabeth Browning of the class. (Yeom, 1998: 110).

سيكون الرجل الجالس في المقدمة المتحدث الرئبسي في هذه الجلسة. .

$$
\begin{array}{r}
\text { 6 } \\
\text { 6. } \\
\text { 6. }
\end{array}
$$

\begin{tabular}{|c|c|c|c|c|c|c|c|c|c|c|}
\hline \multirow{3}{*}{ Title } & \multirow{4}{*}{ No } & \multicolumn{7}{|c|}{ Reference } & \multicolumn{2}{|c|}{ Trans. } \\
\hline & & \multicolumn{3}{|c|}{ Generic } & \multicolumn{3}{|c|}{ Specific } & \multirow{2}{*}{ Unique } & \multirow{2}{*}{ FE } & \multirow{2}{*}{ DE } \\
\hline & & definite & Indefinite & Zero & definite & Indefinite & Zero & & & \\
\hline $\begin{array}{l}\text { SL Text } \\
\text { English }\end{array}$ & & & & & + & & & & & \\
\hline \multirow{6}{*}{$\begin{array}{c}\text { TL Texts } \\
\text { Arabic }\end{array}$} & 1 & & & & + & & & & + & \\
\hline & 2 & & & & + & & & & + & \\
\hline & 3 & & & & + & & & & + & \\
\hline & 4 & & & & + & & & & + & \\
\hline & 5 & & & & + & & & & & + \\
\hline & 6 & & & & + & & & & + & \\
\hline
\end{tabular}

Text Analysis (7):

\begin{tabular}{|c|c|c|c|c|c|c|c|c|c|c|}
\hline \multirow{3}{*}{ Title } & \multirow{4}{*}{ No } & \multicolumn{7}{|c|}{ Reference } & \multicolumn{2}{|c|}{ Trans. } \\
\hline & & & Generic & & & Specific & & \multirow{2}{*}{ Unique } & \multirow{2}{*}{ FE. } & \multirow{2}{*}{ DE } \\
\hline & & definite & Indefinite & Zero & definite & Indefinite & Zero & & & \\
\hline SL Text & & & & & + & & & & & \\
\hline
\end{tabular}

The Proposed Rendering:

جورجيا نجمة الصف اللامعة.

8. The London of 2007 is different from that of 1950's. (Yeom, 1998: 12).

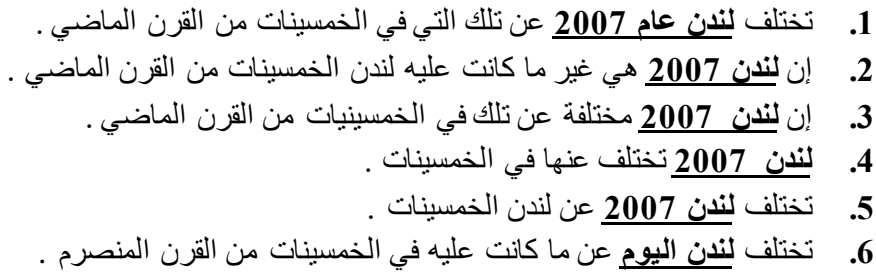

Text Analysis (8): 


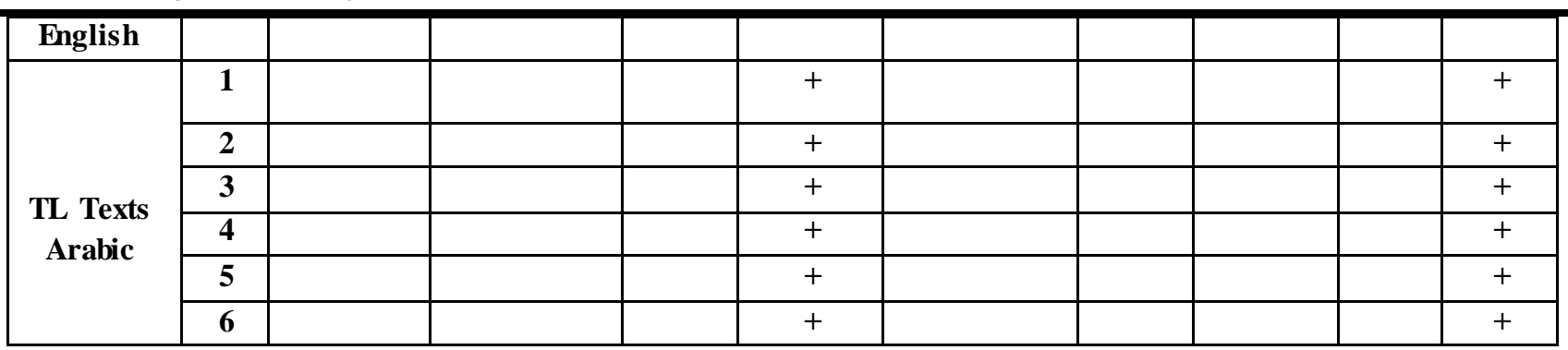

The Proposed Rendering:

لندن 2007 هي غير ما كانت عليه لندن الخمسينات في القرن الماضي.

9. The radio John bought is Japanese. (Quirk et al, 1972: 154).

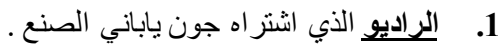
2.

3.

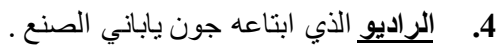

5.

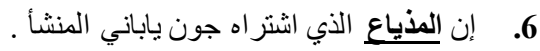

Text Analysis (10):

\begin{tabular}{|c|c|c|c|c|c|c|c|c|c|c|}
\hline \multirow{3}{*}{ Title } & \multirow{4}{*}{ No } & \multicolumn{7}{|c|}{ Reference } & \multicolumn{2}{|c|}{ Trans. } \\
\hline & & \multicolumn{3}{|c|}{ Generic } & \multicolumn{3}{|c|}{ Specific } & \multirow{2}{*}{ Unique } & \multirow{2}{*}{ FE. } & \multirow{2}{*}{ DE } \\
\hline & & definite & Indefinite & Zero & definite & Indefinite & Zero & & & \\
\hline $\begin{array}{l}\text { SL Text } \\
\text { English }\end{array}$ & & & & & + & & & & & \\
\hline \multirow{6}{*}{$\begin{array}{c}\text { TL Texts } \\
\text { Arabic }\end{array}$} & 1 & & & & + & & & & + & \\
\hline & 2 & & & & + & & & & + & \\
\hline & 3 & & & & + & & & & + & \\
\hline & 4 & & & & + & & & & + & \\
\hline & 5 & & & & + & & & & + & \\
\hline & 6 & & & & + & & & & + & \\
\hline
\end{tabular}

The Proposed Rendering:

المذياع الذي اشتراه جون هو من الطراز الياباني.

10. The Philadelphia which Mr. Johnson knows so well is a heritage of colonial times. (Quirk et al, 1972: 155).

$$
\begin{aligned}
& \text { 1. فيلادلفيا التي يعرفها جونسون جيداً هي مير اث العها الاستعماري . }
\end{aligned}
$$

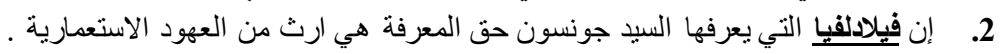

$$
\begin{aligned}
& \text { 3 } \\
& \text { 4. } \\
& \text { 5. } \\
& \text { 6. إن فيلادلفيا التي يعرفها السيد جونسون جيداً هي تراث الأزمنة الاستعمارية . }
\end{aligned}
$$

Text Analysis (11): 


\begin{tabular}{|c|c|c|c|c|c|c|c|c|c|c|}
\hline \multirow{3}{*}{ Title } & \multirow{4}{*}{ No } & \multicolumn{7}{|c|}{ Reference } & \multicolumn{2}{|c|}{ Trans. } \\
\hline & & \multicolumn{3}{|c|}{ Generic } & \multicolumn{3}{|c|}{ Specific } & \multirow{2}{*}{ Unique } & \multirow{2}{*}{ FE. } & \multirow{2}{*}{ DE } \\
\hline & & definite & Indefinite & Zero & definite & Indefinite & Zero & & & \\
\hline $\begin{array}{l}\text { SL Text } \\
\text { English }\end{array}$ & & & & & + & & & & & \\
\hline \multirow{6}{*}{$\begin{array}{c}\text { TL Texts } \\
\text { Arabic }\end{array}$} & 1 & & & & & & + & & & + \\
\hline & 2 & & & & & & + & & & + \\
\hline & 3 & & & & & & + & & & + \\
\hline & 4 & & & & & & + & & & + \\
\hline & 5 & & & & & & + & & & + \\
\hline & 6 & & & & & & + & & & + \\
\hline
\end{tabular}

The Proposed Rendering:

إن فيلادلفيا التي يعرفها السيد جونسون حق المعرفة هي ارث من العهود الاستعمارية .

11. Mary considered John the genius of the family. (Quirk et al, 1972: 159).

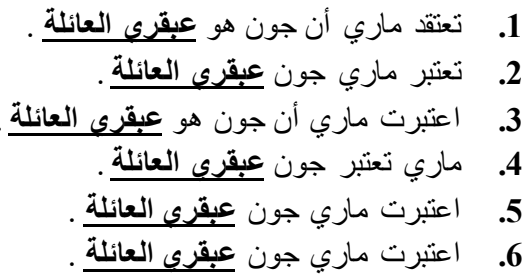

Text Analysis (12):

\begin{tabular}{|c|c|c|c|c|c|c|c|c|c|c|}
\hline \multirow{3}{*}{ Title } & \multirow{4}{*}{ No } & \multicolumn{7}{|c|}{ Reference } & \multicolumn{2}{|c|}{ Trans. } \\
\hline & & \multicolumn{3}{|c|}{ Generic } & \multicolumn{3}{|c|}{ Specific } & \multirow{2}{*}{ Unique } & \multirow{2}{*}{ FE } & \multirow{2}{*}{ DE } \\
\hline & & definite & Indefinite & Zero & definite & Indefinite & Zero & & & \\
\hline $\begin{array}{l}\text { SL Text } \\
\text { English }\end{array}$ & & & & & + & & & & & \\
\hline \multirow{6}{*}{$\begin{array}{c}\text { TL Texts } \\
\text { Arabic }\end{array}$} & 1 & & & & + & & & & & + \\
\hline & 2 & & & & + & & & & & + \\
\hline & 3 & & & & + & & & & & + \\
\hline & 4 & & & & + & & & & & + \\
\hline & 5 & & & & + & & & & & + \\
\hline & 6 & & & & + & & & & & + \\
\hline
\end{tabular}

The Proposed Rendering:

عدت ماري جون عبقري العائلة.

\subsubsection{Specific Reference / Indefinite:}

1. A friend of mine is going to graduate soon. He is very smart. (Yeom, 1998: 4). 
Text Analysis (1):

\begin{tabular}{|c|c|c|c|c|c|c|c|c|c|c|}
\hline \multirow{3}{*}{ Title } & \multirow{4}{*}{ No } & \multicolumn{7}{|c|}{ Reference } & \multicolumn{2}{|c|}{ Trans. } \\
\hline & & \multicolumn{3}{|c|}{ Generic } & \multicolumn{3}{|c|}{ Specific } & \multirow{2}{*}{ Unique } & \multirow{2}{*}{ FE. } & \multirow{2}{*}{ DE } \\
\hline & & definite & Indefinite & Zero & definite & Indefinite & Zero & & & \\
\hline $\begin{array}{l}\text { SL Text } \\
\text { English }\end{array}$ & & & & & & + & & & & \\
\hline \multirow{6}{*}{$\begin{array}{c}\text { TL Texts } \\
\text { Arabic }\end{array}$} & 1 & & & & & & + & & & + \\
\hline & 2 & & & & & & + & & & + \\
\hline & 3 & & & & & & + & & & + \\
\hline & 4 & & & & & & + & & & + \\
\hline & 5 & & & & & + & & & + & \\
\hline & 6 & & & & & & + & & & + \\
\hline
\end{tabular}

The Proposed Rendering:

عما قريب سيتخرج احد أصدقائي. انه يتمتع بذكاء حاد .

2. I met a man from York last night, but I did not meet Jones last night. (Yeom, 1998: 16).

$$
\begin{aligned}
& \text { 1. التقيت رجلاً من يورك الليلة الماضية ولم التقِ جون في تلك الليلة . }
\end{aligned}
$$

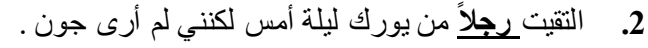

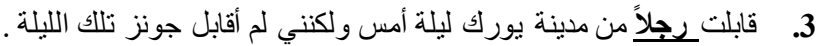

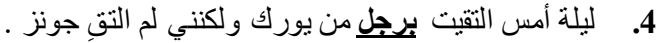

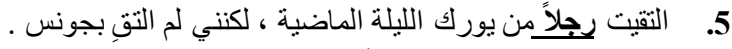

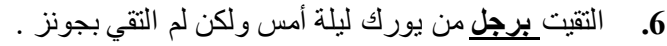

Text Analysis (2):

\begin{tabular}{|c|c|c|c|c|c|c|c|c|c|c|}
\hline \multirow{3}{*}{ Title } & \multirow{4}{*}{ No } & \multicolumn{7}{|c|}{ Reference } & \multicolumn{2}{|c|}{ Trans. } \\
\hline & & \multicolumn{3}{|c|}{ Generic } & \multicolumn{3}{|c|}{ Specific } & \multirow{2}{*}{ Unique } & \multirow{2}{*}{ FE. } & \multirow{2}{*}{ DE. } \\
\hline & & definite & Indefinite & Zero & definite & Indefinite & Zero & & & \\
\hline $\begin{array}{l}\text { SL Text } \\
\text { English }\end{array}$ & & & & & & + & & & & \\
\hline \multirow{6}{*}{$\begin{array}{c}\text { TL Texts } \\
\text { Arabic }\end{array}$} & 1 & & & & & + & & & + & \\
\hline & 2 & & & & & + & & & + & \\
\hline & 3 & & & & & + & & & + & \\
\hline & 4 & & & & & + & & & + & \\
\hline & 5 & & & & & + & & & + & \\
\hline & 6 & & & & & + & & & + & \\
\hline
\end{tabular}

\section{The Proposed Rendering:}


3. Alberto believes that a dragon ate her petunias. (Yeom, 1998: 46).

1 . يظن البيرنو ان حيواناً كالتنين أكل نبتاتها .

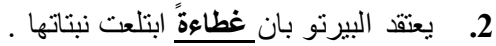

3.

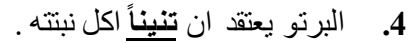

6.

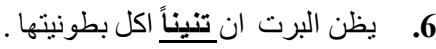

Text Analysis (3):

\begin{tabular}{|c|c|c|c|c|c|c|c|c|c|c|}
\hline \multirow{3}{*}{ Title } & \multirow{4}{*}{ No } & \multicolumn{7}{|c|}{ Reference } & \multicolumn{2}{|c|}{ Trans. } \\
\hline & & \multicolumn{3}{|c|}{ Generic } & \multicolumn{3}{|c|}{ Specific } & \multirow{2}{*}{ Unique } & \multirow{2}{*}{ FE. } & \multirow{2}{*}{ DE. } \\
\hline & & definite & Indefinite & Zero & definite & Indefinite & Zero & & & \\
\hline $\begin{array}{l}\text { SL Text } \\
\text { English }\end{array}$ & & & & & & + & & & & \\
\hline \multirow{6}{*}{$\begin{array}{c}\text { TL Texts } \\
\text { Arabic }\end{array}$} & 1 & & & & & + & & & + & \\
\hline & 2 & & & & & + & & & + & \\
\hline & 3 & & & & & + & & & + & \\
\hline & 4 & & & & & + & & & + & \\
\hline & 5 & & & & & + & & & + & \\
\hline & 6 & & & & & + & & & + & \\
\hline
\end{tabular}

\section{The Proposed Rendering:}

7. يعتقد البيرتا ان عظاية ابتلعت نبتاتها .

4. Everyone hates a student in the semantics class who sleeps, snoring at the back of the classroom. (Yeom, 1998: 40).

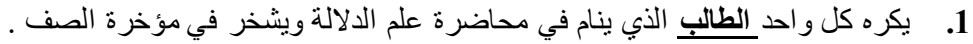

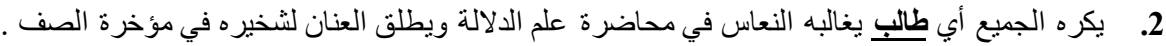

$$
\begin{aligned}
& \text { 3. }
\end{aligned}
$$

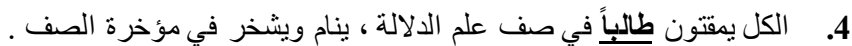

$$
\begin{aligned}
& \text { 5. } \\
& \text { 6. يكره الجميع الطالب الذي يغطنومأ في محاضرة علم الدلالة وهو يشخر في مؤخرة قاعة الدرس. }
\end{aligned}
$$

\begin{tabular}{|c|c|c|c|c|c|c|c|c|c|c|}
\hline \multirow{3}{*}{ Title } & \multirow{4}{*}{ No } & \multicolumn{7}{|c|}{ Reference } & \multicolumn{2}{|c|}{ Trans. } \\
\hline & & \multicolumn{3}{|c|}{ Generic } & \multicolumn{3}{|c|}{ Specific } & \multirow{2}{*}{ Unique } & \multirow{2}{*}{ FE } & \multirow{2}{*}{ DE. } \\
\hline & & definite & Indefinite & Zero & definite & Indefinite & Zero & & & \\
\hline \multirow[t]{4}{*}{$\begin{array}{l}\text { SL Text } \\
\text { English }\end{array}$} & & & & & & + & & & & \\
\hline & 1 & & & & + & & & & & + \\
\hline & 2 & & & & & + & & & + & \\
\hline & 3 & & & & & + & & & + & \\
\hline
\end{tabular}

Text Analysis (4): 


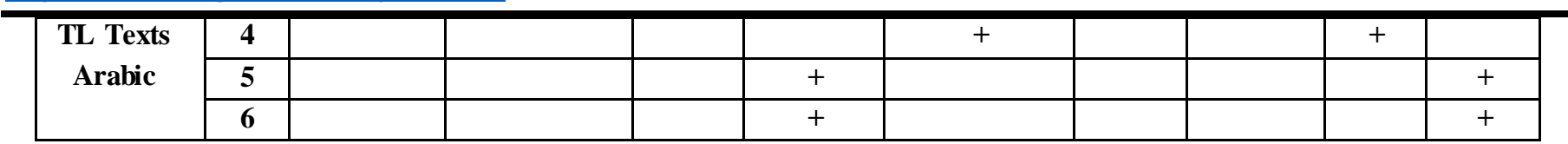

\section{The Proposed Rendering:}

$$
\text { يكره الجميع أي طالب يغالبه النعاس في محاضرة علم الدلالة ويطلق العنان لشخيره في مؤخرة الصف . }
$$

5. A Mrs. Robertson was trying to contact you this morning. (Quirk et al, 1985: 289).

$$
\begin{aligned}
& \text { 1. حاولت امر أة تدعو ا نفسها السيدة روبيرستون الاتصال بك هذا الصباح . } \\
& \text { 2. كانت سيذة تدعى روبيرتسون تحاول الاتصال بك هذا الصباح . }
\end{aligned}
$$

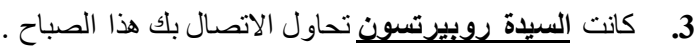

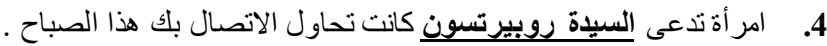

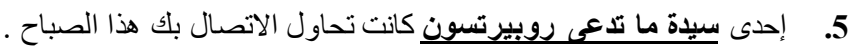

\begin{tabular}{|c|c|c|c|c|c|c|c|c|c|c|}
\hline \multirow{3}{*}{ Title } & \multirow{4}{*}{ No } & \multicolumn{7}{|c|}{ Reference } & \multicolumn{2}{|c|}{ Trans. } \\
\hline & & \multicolumn{3}{|c|}{ Generic } & \multicolumn{3}{|c|}{ Specific } & \multirow{2}{*}{ Unique } & \multirow{2}{*}{ FE } & \multirow{2}{*}{ DE } \\
\hline & & definite & Indefinite & Zero & definite & Indefinite & Zero & & & \\
\hline $\begin{array}{l}\text { SL Text } \\
\text { English }\end{array}$ & & & & & & + & & & & \\
\hline \multirow{6}{*}{$\begin{array}{c}\text { TL Texts } \\
\text { Arabic }\end{array}$} & 1 & & & & + & & & & & + \\
\hline & 2 & & & & & + & & & + & \\
\hline & 3 & & & & + & & & & & + \\
\hline & 4 & & & & + & & & & & + \\
\hline & 5 & & & & & + & & & + & \\
\hline & 6 & & & & & + & & & + & \\
\hline
\end{tabular}

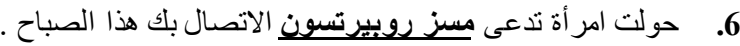

Text Analysis (5):

The Proposed Rendering:

6. An intruder has stolen the vase from a locked case. (Quirk et al, 185: 272).

سياة ما تدعى روبيزتسون كانت تحاول الاتصال بك هذا الصباح.

1

2.

3.

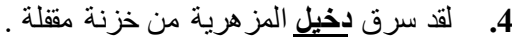

5. 5 . سرق متطفل المز هرية من خز انة مقفلة .

\begin{tabular}{|c|c|c|c|c|c|c|c|c|c|c|}
\hline \multirow{3}{*}{ Title } & \multirow{3}{*}{ No } & \multicolumn{7}{|c|}{ Reference } & \multicolumn{2}{|c|}{ Trans. } \\
\hline & & \multicolumn{3}{|c|}{ Generic } & \multicolumn{3}{|c|}{ Specific } & \multirow{2}{*}{ Unique } & \multirow{2}{*}{ FE } & \multirow{2}{*}{ DE } \\
\hline & & definite & Indefinite & Zero & definite & Indefinite & Zero & & & \\
\hline
\end{tabular}

6. سرق دخيل مز هرية من صندوق مقلل .

Text Analysis (6): 


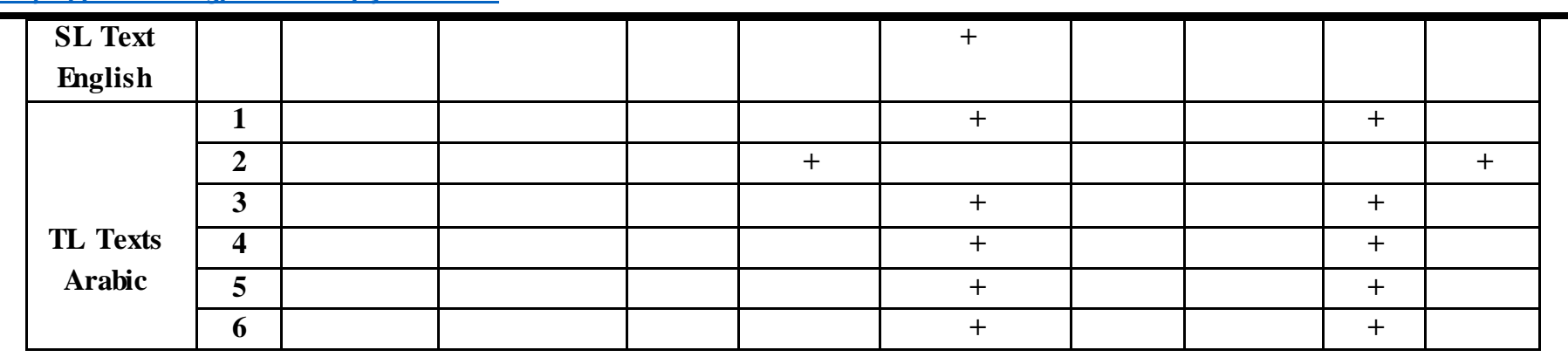

\section{The Proposed Rendering:}

$$
\text { لقد سرق احد المتطقلين المز هرية من إحدى الخزانات المقلة . }
$$

7. A girl who makes him weak in the knees has just come into the room. (Quirk et al, 1972: 154).

1. لقد دخلت نو اً إلى الغرفة الفتاة التي جعلته ضعيف الثخصية .

2.

3. إن القتاة التي تجعله عاجزاً عن الوقوف على ركبنيه من الخوف قد دخلت الغرفة في هذه اللحظة.

4.

5.

6. دخلت تواً الفتاة التي تجعله يجثي على ركبنيه .

Text Analysis (7):

\begin{tabular}{|c|c|c|c|c|c|c|c|c|c|c|}
\hline \multirow{3}{*}{ Title } & \multirow{4}{*}{ No } & \multicolumn{7}{|c|}{ Reference } & \multicolumn{2}{|c|}{ Trans. } \\
\hline & & \multicolumn{3}{|c|}{ Generic } & \multicolumn{3}{|c|}{ Specific } & \multirow{2}{*}{ Unique } & \multirow{2}{*}{ FE } & \multirow{2}{*}{ DE } \\
\hline & & definite & Indefinite & Zero & definite & Indefinite & Zero & & & \\
\hline $\begin{array}{l}\text { SL Text } \\
\text { English }\end{array}$ & & & & & & + & & & & \\
\hline \multirow{6}{*}{$\begin{array}{c}\text { TL Texts } \\
\text { Arabic }\end{array}$} & 1 & & & & + & & & & & + \\
\hline & 2 & & & & + & & & & & + \\
\hline & 3 & & & & + & & & & & + \\
\hline & 4 & & & & + & & & & & + \\
\hline & 5 & & & & + & & & & & + \\
\hline & 6 & & & & + & & & & & + \\
\hline
\end{tabular}

The Proposed Rendering:

لقد دخلت الفتاة التي سلبت عقله الغرفة للتو .

8. We need a Sibawayhi to solve this problem. (Aziz, 1989: 106).

Text Analysis (8): 


\begin{tabular}{|c|c|c|c|c|c|c|c|c|c|c|}
\hline \multirow{2}{*}{ Title } & \multirow{3}{*}{ No } & \multicolumn{3}{|c|}{ Generic } & \multicolumn{3}{|c|}{ Specific } & \multirow{2}{*}{ Unique } & \multirow{2}{*}{ FE } & \multirow{2}{*}{ DE } \\
\hline & & definite & Indefinite & Zero & definite & Indefinite & Zero & & & \\
\hline $\begin{array}{l}\text { SL Text } \\
\text { English }\end{array}$ & & & & & & + & & & & \\
\hline \multirow{6}{*}{$\begin{array}{c}\text { TL Texts } \\
\text { Arabic }\end{array}$} & 1 & & & & & & + & & & + \\
\hline & 2 & & & & & & + & & & + \\
\hline & 3 & & & & & & + & & & + \\
\hline & 4 & & & & & & + & & & + \\
\hline & 5 & & & & & & + & & & + \\
\hline & 6 & & & & & & + & & & + \\
\hline
\end{tabular}

The Proposed Rendering:

\subsubsection{Specific Reference / Zero Article / Some:}

نحتاج إلى سيويه لحل هذه المعضلة .

1. We have just received some news from Cairo. (Quirk et al, 1985: 275).

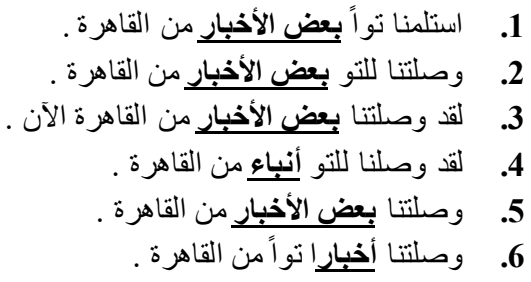

Text Analysis (1):

\begin{tabular}{|c|c|c|c|c|c|c|c|c|c|c|}
\hline \multirow{3}{*}{ Title } & \multirow{4}{*}{ No } & \multicolumn{7}{|c|}{ Reference } & \multicolumn{2}{|c|}{ Trans. } \\
\hline & & \multicolumn{3}{|c|}{ Generic } & \multicolumn{3}{|c|}{ Specific } & \multirow{2}{*}{ Unique } & \multirow{2}{*}{ FE } & \multirow{2}{*}{ DE } \\
\hline & & definite & Indefinite & Zero & definite & Indefinite & Zero & & & \\
\hline $\begin{array}{l}\text { SL Text } \\
\text { English }\end{array}$ & & & & & & & + & & & \\
\hline \multirow{6}{*}{$\begin{array}{c}\text { TL Texts } \\
\text { Arabic }\end{array}$} & $\mathbf{1}$ & & & & + & & & & & + \\
\hline & 2 & & & & + & & & & & + \\
\hline & 3 & & & & + & & & & & + \\
\hline & 4 & & & & & + & & & & + \\
\hline & 5 & & & & + & & & & & + \\
\hline & 6 & & & & & + & & & & + \\
\hline
\end{tabular}

\section{The Proposed Rendering:}

2. She is at church, arranging flowers. (Quirk et al, 1985: 277). 
Text Analysis (2):

\begin{tabular}{|c|c|c|c|c|c|c|c|c|c|c|}
\hline \multirow{3}{*}{ Title } & \multirow{4}{*}{ No } & \multicolumn{7}{|c|}{ Reference } & \multicolumn{2}{|c|}{ Trans. } \\
\hline & & \multicolumn{3}{|c|}{ Generic } & \multicolumn{3}{|c|}{ Specific } & \multirow[t]{2}{*}{ Unique } & \multirow[t]{2}{*}{ FE. } & \multirow[t]{2}{*}{ DE } \\
\hline & & definite & Indefinite & Zero & definite & Indefinite & Zero & & & \\
\hline $\begin{array}{l}\text { SL Text } \\
\text { English }\end{array}$ & & & & & & & + & & & \\
\hline \multirow{6}{*}{$\begin{array}{c}\text { TL Texts } \\
\text { Arabic }\end{array}$} & 1 & & & & + & & & & & + \\
\hline & 2 & & & & + & & & & & + \\
\hline & 3 & & & & + & & & & & + \\
\hline & 4 & & & & + & & & & & + \\
\hline & 5 & & & & + & & & & & + \\
\hline & 6 & & & & + & & & & & + \\
\hline
\end{tabular}

\section{The Proposed Rendering:}

3. Winter in 1963 was not like this winter. (Quirk et al, 1985: 279).

Text Analysis (3):

\begin{tabular}{|c|c|c|c|c|c|c|c|c|c|c|}
\hline \multirow{3}{*}{ Title } & \multirow{4}{*}{ No } & \multicolumn{7}{|c|}{ Reference } & \multicolumn{2}{|c|}{ Trans. } \\
\hline & & \multicolumn{3}{|c|}{ Generic } & \multicolumn{3}{|c|}{ Specific } & \multirow{2}{*}{ Unique } & \multirow{2}{*}{ FE } & \multirow{2}{*}{ DE } \\
\hline & & definite & Indefinite & Zero & definite & Indefinite & Zero & & & \\
\hline \multirow[t]{3}{*}{$\begin{array}{l}\text { SL Text } \\
\text { English }\end{array}$} & & & & & & & + & & & \\
\hline & 1 & & & & + & & & & & + \\
\hline & 2 & & & & + & & & & & + \\
\hline
\end{tabular}


TL Texts

Arabic

\begin{tabular}{|c|l|l|l|r|}
\hline $\mathbf{3}$ & & & & + \\
\hline $\mathbf{4}$ & & & & + \\
\hline $\mathbf{5}$ & & & & + \\
\hline $\mathbf{6}$ & & & & + \\
\hline
\end{tabular}

The Proposed Rendering:

4. That day, lunch was served on the terrace. (Quirk et al, 1998: 279).

Text Analysis (4):

\begin{tabular}{|c|c|c|c|c|c|c|c|c|c|c|}
\hline \multirow{3}{*}{ Title } & \multirow{4}{*}{ No } & \multicolumn{7}{|c|}{ Reference } & \multicolumn{2}{|c|}{ Trans. } \\
\hline & & \multicolumn{3}{|c|}{ Generic } & \multicolumn{3}{|c|}{ Specific } & \multirow{2}{*}{ Unique } & \multirow{2}{*}{ FE } & \multirow{2}{*}{ DE. } \\
\hline & & definite & Indefinite & Zero & definite & Indefinite & Zero & & & \\
\hline $\begin{array}{l}\text { SL Text } \\
\text { English }\end{array}$ & & & & & & & + & & & \\
\hline \multirow{6}{*}{$\begin{array}{c}\text { TL Texts } \\
\text { Arabic }\end{array}$} & 1 & & & & + & & & & & + \\
\hline & 2 & & & & + & & & & & + \\
\hline & 3 & & & & + & & & & & + \\
\hline & 4 & & & & + & & & & & + \\
\hline & 5 & & & & + & & & & & + \\
\hline & 6 & & & & + & & & & & + \\
\hline
\end{tabular}

\section{The Proposed Rendering:}

5. They talked face-to-face. (Quirk et al, 1985: 280). 


\begin{tabular}{|c|c|c|c|c|c|c|c|c|c|c|}
\hline \multirow{3}{*}{ Title } & \multirow{4}{*}{ No } & \multicolumn{7}{|c|}{ Reference } & \multicolumn{2}{|c|}{ Trans. } \\
\hline & & \multicolumn{3}{|c|}{ Generic } & \multicolumn{3}{|c|}{ Specific } & \multirow{2}{*}{ Unique } & \multirow{2}{*}{ FE. } & \multirow{2}{*}{ DE } \\
\hline & & definite & Indefinite & Zero & definite & Indefinite & Zero & & & \\
\hline $\begin{array}{l}\text { SL Text } \\
\text { English }\end{array}$ & & & & & & & + & & & \\
\hline \multirow{6}{*}{$\begin{array}{c}\text { TL Texts } \\
\text { Arabic }\end{array}$} & 1 & & & & + & & & & & + \\
\hline & 2 & & & & + & & & & & + \\
\hline & 3 & & & & + & & & & & + \\
\hline & 4 & & & & + & & & & & + \\
\hline & 5 & & & & + & & & & & + \\
\hline & 6 & & & & + & & & & & + \\
\hline
\end{tabular}

The Proposed Rendering:

6. The birth took place this morning, and both mother and child are doing well. (Quirk et al, 1985: 280).

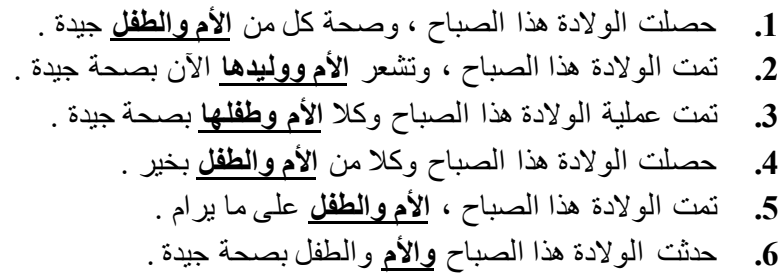

Text Analysis (6):

\begin{tabular}{|c|c|c|c|c|c|c|c|c|c|c|}
\hline \multirow{3}{*}{ Title } & \multirow{4}{*}{ No } & \multicolumn{7}{|c|}{ Reference } & \multicolumn{2}{|c|}{ Trans. } \\
\hline & & \multicolumn{3}{|c|}{ Generic } & \multicolumn{3}{|c|}{ Specific } & \multirow{2}{*}{ Unique } & \multirow{2}{*}{ FE. } & \multirow{2}{*}{ DE } \\
\hline & & definite & Indefinite & Zero & definite & Indefinite & Zero & & & \\
\hline $\begin{array}{l}\text { SL Text } \\
\text { English }\end{array}$ & & & & & & & + & & & \\
\hline \multirow{5}{*}{$\begin{array}{c}\text { TL Texts } \\
\text { Arabic }\end{array}$} & 1 & & & & + & & & & & + \\
\hline & 2 & & & & + & & & & & + \\
\hline & 3 & & & & + & & & & & + \\
\hline & 4 & & & & + & & & & & + \\
\hline & 5 & & & & + & & & & & + \\
\hline
\end{tabular}


The Proposed Rendering:

7. He took advantage of the situation. (Quirk et al, 1985: 281).

Text Analysis (7):

\begin{tabular}{|c|c|c|c|c|c|c|c|c|c|c|}
\hline \multirow{3}{*}{ Title } & \multirow{4}{*}{ No } & \multicolumn{7}{|c|}{ Reference } & \multicolumn{2}{|c|}{ Trans. } \\
\hline & & \multicolumn{3}{|c|}{ Generic } & \multicolumn{3}{|c|}{ Specific } & \multirow{2}{*}{ Unique } & \multirow{2}{*}{ FE. } & \multirow{2}{*}{ DE. } \\
\hline & & definite & Indefinite & Zero & definite & Indefinite & Zero & & & \\
\hline $\begin{array}{c}\text { SL Text } \\
\text { English }\end{array}$ & & & & & & & + & & & \\
\hline \multirow{6}{*}{$\begin{array}{c}\text { TL Texts } \\
\text { Arabic }\end{array}$} & 1 & & & & + & & & & & + \\
\hline & 2 & & & & + & & & & & + \\
\hline & 3 & & & & + & & & & & + \\
\hline & 4 & & & & + & & & & & + \\
\hline & 5 & & & & + & & & & & + \\
\hline & 6 & & & & + & & & & & + \\
\hline
\end{tabular}

\section{The Proposed Rendering:}

8. Mr. Johnson knows Philadelphia so well. (Quirk et al, 1972: 155).

$$
\begin{aligned}
& \text { 1. } \\
& \text { 2. يعرف السيد جونسون فيلادلفيا جيداً . }
\end{aligned}
$$

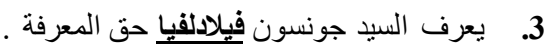

$$
\begin{aligned}
& \text { 4. السيد جونسون يعرف فيلادلفيا جيداً . } \\
& \text { 5. . يعرف السيد جونسون فيلادلفيا جيداً . } \\
& \text { 6. يعرف السيد جونسون فيلادلفيا حق المعرفة جليا . }
\end{aligned}
$$

Text Analysis (8):

\begin{tabular}{|l|l|l|l|}
\hline & Reference & Trans. \\
\hline
\end{tabular}




\begin{tabular}{|c|c|c|c|c|c|c|c|c|c|c|}
\hline \multirow{2}{*}{ Title } & \multirow{3}{*}{ No } & \multicolumn{3}{|c|}{ Generic } & \multicolumn{3}{|c|}{ Specific } & \multirow{2}{*}{ Unique } & \multirow{2}{*}{ FE. } & \multirow{2}{*}{ DE } \\
\hline & & definite & Indefinite & Zero & definite & Indefinite & Zero & & & \\
\hline $\begin{array}{l}\text { SL Text } \\
\text { English }\end{array}$ & & & & & & & + & & & \\
\hline \multirow{6}{*}{$\begin{array}{c}\text { TL Texts } \\
\text { Arabic }\end{array}$} & 1 & & & & & & + & & + & \\
\hline & 2 & & & & & & + & & + & \\
\hline & 3 & & & & & & + & & + & \\
\hline & 4 & & & & & & + & & + & \\
\hline & 5 & & & & & & + & & + & \\
\hline & 6 & & & & & & + & & + & \\
\hline
\end{tabular}

The Proposed Rendering:

9. He went to church. (Neuman, 1981: 13).

$$
\text { يعرف السيد جونسون فيلادلفيا حق المعرفة . }
$$

1. - مهب إلى الكنيسة.

2.

3. ذ. ذهب إلى الكنيسة.

4.

6.

6.

Text Analysis (9):

\begin{tabular}{|c|c|c|c|c|c|c|c|c|c|c|}
\hline \multirow{3}{*}{ Title } & \multirow{4}{*}{ No } & \multicolumn{7}{|c|}{ Reference } & \multicolumn{2}{|c|}{ Trans. } \\
\hline & & \multicolumn{3}{|c|}{ Generic } & \multicolumn{3}{|c|}{ Specific } & \multirow{2}{*}{ Unique } & \multirow{2}{*}{ FE. } & \multirow{2}{*}{ DE } \\
\hline & & definite & Indefinite & Zero & definite & Indefinite & Zero & & & \\
\hline $\begin{array}{l}\text { SL Text } \\
\text { English }\end{array}$ & & & & & & & + & & & \\
\hline \multirow{6}{*}{$\begin{array}{c}\text { TL Texts } \\
\text { Arabic }\end{array}$} & 1 & & & & + & & & & + & \\
\hline & 2 & & & & + & & & & + & \\
\hline & 3 & & & & + & & & & + & \\
\hline & 4 & & & & + & & & & + & \\
\hline & 5 & & & & + & & & & + & \\
\hline & 6 & & & & + & & & & + & \\
\hline
\end{tabular}


The Proposed Rendering:

10. She went home. (Neuman, 1981: 13).

1.

2.

3.

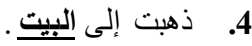

6.

6. هبت إلى البيث.

Text Analysis (10):

\begin{tabular}{|c|c|c|c|c|c|c|c|c|c|c|}
\hline \multirow{3}{*}{ Title } & \multirow{4}{*}{ No } & \multicolumn{7}{|c|}{ Reference } & \multicolumn{2}{|c|}{ Trans. } \\
\hline & & \multicolumn{3}{|c|}{ Generic } & \multicolumn{3}{|c|}{ Specific } & \multirow{2}{*}{ Unique } & \multirow{2}{*}{ FE } & \multirow{2}{*}{ DE } \\
\hline & & definite & Indefinite & Zero & definite & Indefinite & Zero & & & \\
\hline $\begin{array}{l}\text { SL Text } \\
\text { English }\end{array}$ & & & & & & & + & & & \\
\hline \multirow{6}{*}{$\begin{array}{c}\text { TL Texts } \\
\text { Arabic }\end{array}$} & 1 & & & & + & & & & + & \\
\hline & 2 & & & & + & & & & + & \\
\hline & 3 & & & & + & & & & + & \\
\hline & 4 & & & & + & & & & + & \\
\hline & 5 & & & & + & & & & + & \\
\hline & 6 & & & & + & & & & + & \\
\hline
\end{tabular}

The Proposed Rendering:

11. She has men as well as women on her staff. (Greenbaum, and Quirk, 1990: 81).

$$
\begin{aligned}
& \text { 1 . يتكون كادر ها من الرجال و النساء . }
\end{aligned}
$$

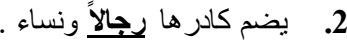

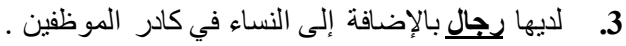

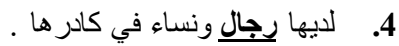

$$
\begin{aligned}
& \text { 5. }
\end{aligned}
$$

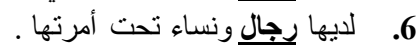

Text Analysis (11):

\begin{tabular}{|c|c|c|c|c|c|}
\hline & & \multicolumn{3}{|c|}{ Reference } & \\
\cline { 3 - 6 } & & Generic & Specific & & \\
\cline { 3 - 7 } & Nitle & No & & & \\
\hline
\end{tabular}




\begin{tabular}{|c|c|c|c|c|c|c|c|c|c|c|}
\hline & & definite & Indefinite & Zero & definite & Indefinite & Zero & Unique & FE & DE \\
\hline $\begin{array}{l}\text { SL Text } \\
\text { English }\end{array}$ & & & & & & & + & & & \\
\hline \multirow{6}{*}{$\begin{array}{c}\text { TL Texts } \\
\text { Arabic }\end{array}$} & 1 & & & & + & & & & & + \\
\hline & $\overline{2}$ & & & & & + & & & + & \\
\hline & 3 & & & & & + & & & + & \\
\hline & 4 & & & & & + & & & + & \\
\hline & 5 & & & & & + & & & + & \\
\hline & 6 & & & & & + & & & + & \\
\hline
\end{tabular}

The Proposed Rendering:

$$
\text { يضم كادر ها رجالاً ونساءاً. }
$$

\subsubsection{Unique Reference:}

1. Washington is the capital of United States of America. (Yeom, 1998: 20).

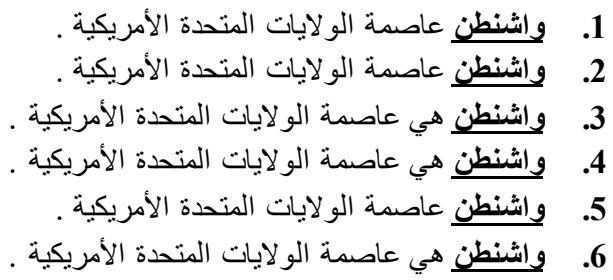

Text Analysis (1):

\begin{tabular}{|c|c|c|c|c|c|c|c|c|c|c|}
\hline \multirow{3}{*}{ Title } & \multirow{4}{*}{ No } & \multicolumn{7}{|c|}{ Reference } & \multicolumn{2}{|c|}{ Trans. } \\
\hline & & \multicolumn{3}{|c|}{ Generic } & \multicolumn{3}{|c|}{ Specific } & \multirow{2}{*}{ Unique } & \multirow{2}{*}{ FE. } & \multirow{2}{*}{ DE. } \\
\hline & & definite & Indefinite & Zero & definite & Indefinite & Zero & & & \\
\hline $\begin{array}{l}\text { SL Text } \\
\text { English }\end{array}$ & & & & & & & & + & & \\
\hline \multirow{6}{*}{$\begin{array}{c}\text { TL Texts } \\
\text { Arabic }\end{array}$} & 1 & & & & & & & + & + & \\
\hline & 2 & & & & & & & + & + & \\
\hline & 3 & & & & & & & + & + & \\
\hline & 4 & & & & & & & + & + & \\
\hline & 5 & & & & & & & + & + & \\
\hline & 6 & & & & & & & + & + & \\
\hline
\end{tabular}

\section{The Proposed Rendering:}

$$
\text { و واشنطن عاصمة الولايات المتحدة الأمريكية . }
$$

2. President Kennedy was as sassinated in the United States of America. (Yeom, 1998: 22).

$$
\text { 2. }
$$


Text Analysis (2):

\begin{tabular}{|c|c|c|c|c|c|c|c|c|c|c|}
\hline \multirow{3}{*}{ Title } & \multirow{4}{*}{ No } & \multicolumn{7}{|c|}{ Reference } & \multicolumn{2}{|c|}{ Trans. } \\
\hline & & \multicolumn{3}{|c|}{ Generic } & \multicolumn{3}{|c|}{ Specific } & \multirow{2}{*}{ Unique } & \multirow{2}{*}{ FE. } & \multirow{2}{*}{ DE } \\
\hline & & definite & Indefinite & Zero & definite & Indefinite & Zero & & & \\
\hline $\begin{array}{l}\text { SL Text } \\
\text { English }\end{array}$ & & & & & & & & + & & \\
\hline \multirow{6}{*}{$\begin{array}{c}\text { TL Texts } \\
\text { Arabic }\end{array}$} & 1 & & & & & & & + & + & \\
\hline & 2 & & & & & & & + & + & \\
\hline & 3 & & & & & & & + & + & \\
\hline & 4 & & & & & & & + & + & \\
\hline & 5 & & & & & & & + & + & \\
\hline & 6 & & & & & & & + & + & \\
\hline
\end{tabular}

The Proposed Rendering:

3. The Suez Canal was nationalized in 1956. (Yeom, 1998: 30).

Text Analysis (3):

\begin{tabular}{|c|c|c|c|c|c|c|c|c|c|c|}
\hline \multirow{3}{*}{ Title } & \multirow{3}{*}{ No } & \multicolumn{7}{|c|}{ Reference } & \multicolumn{2}{|c|}{ Trans. } \\
\hline & & \multicolumn{3}{|c|}{ Generic } & \multicolumn{3}{|c|}{ Specific } & \multirow{2}{*}{ Unique } & \multirow{2}{*}{ FE. } & \multirow{2}{*}{ DE } \\
\hline & & definite & Indefinite & Zero & definite & Indefinite & Zero & & & \\
\hline $\begin{array}{l}\text { SL Text } \\
\text { English }\end{array}$ & & & & & & & & + & & \\
\hline
\end{tabular}


TL Texts

\begin{tabular}{|l|l|l|}
\hline 1 & & \\
\hline 2 & & \\
\hline 3 & & \\
\hline 4 & & \\
\hline 5 & & \\
\hline 6 & & \\
\hline
\end{tabular}

\begin{tabular}{|l|l|l|l|}
\hline & & & \\
\hline & & & \\
\hline & & & \\
\hline & & & \\
\hline & & &
\end{tabular}

The Proposed Rendering:

تم تأميم قناة السويس في عام 1956 ـ

4. The Wilsons attended his party. (Yeom, 1998: 31).

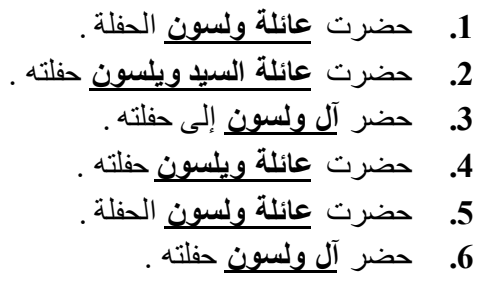

Text Analysis (4):

\begin{tabular}{|c|c|c|c|c|c|c|c|c|c|c|}
\hline \multirow{3}{*}{ Title } & \multirow{4}{*}{ No } & \multicolumn{7}{|c|}{ Reference } & \multicolumn{2}{|c|}{ Trans. } \\
\hline & & \multicolumn{3}{|c|}{ Generic } & \multicolumn{3}{|c|}{ Specific } & \multirow{2}{*}{ Unique } & \multirow{2}{*}{ FE } & \multirow{2}{*}{ DE } \\
\hline & & definite & Indefinite & Zero & definite & Indefinite & Zero & & & \\
\hline $\begin{array}{l}\text { SL Text } \\
\text { English }\end{array}$ & & & & & & & & + & & \\
\hline \multirow{6}{*}{$\begin{array}{c}\text { TL Texts } \\
\text { Arabic }\end{array}$} & 1 & & & & & & & + & + & \\
\hline & 2 & & & & & & & + & + & \\
\hline & 3 & & & & & & & + & + & \\
\hline & 4 & & & & & & & + & + & \\
\hline & 5 & & & & & & & + & + & \\
\hline & $\overline{6}$ & & & & & & & + & + & \\
\hline
\end{tabular}

The Proposed Rendering:

5. Christians have their own celebrations during Easter. (Yeom, 1998: 41). 
Text Analysis (5):

\begin{tabular}{|c|c|c|c|c|c|c|c|c|c|c|}
\hline \multirow{3}{*}{ Title } & \multirow{4}{*}{ No } & \multicolumn{7}{|c|}{ Reference } & \multicolumn{2}{|c|}{ Trans. } \\
\hline & & \multicolumn{3}{|c|}{ Generic } & \multicolumn{3}{|c|}{ Specific } & \multirow{2}{*}{ Unique } & \multirow{2}{*}{ FE. } & \multirow{2}{*}{ DE. } \\
\hline & & definite & Indefinite & Zero & definite & Indefinite & Zero & & & \\
\hline $\begin{array}{l}\text { SL Text } \\
\text { English }\end{array}$ & & & & & & & & + & & \\
\hline \multirow{6}{*}{$\begin{array}{c}\text { TL Texts } \\
\text { Arabic }\end{array}$} & 1 & & & & & & & + & + & \\
\hline & 2 & & & & & & & + & + & \\
\hline & 3 & & & & & & & + & + & \\
\hline & 4 & & & & & & & + & + & \\
\hline & 5 & & & & & & & + & + & \\
\hline & 6 & & & & & & & + & + & \\
\hline
\end{tabular}

The Proposed Rendering:

يقيم النصارى احتفالاتهم الخاصة أثناء عيد الفصح .

6. The Euphrates runs through Iraq. (Yeom, 1998: 47).

$$
\begin{aligned}
& \text { 1. } \\
& \text { 2. يجري الفرات عبر الأراضي العراقية . }
\end{aligned}
$$

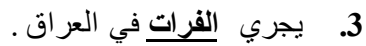

$$
\begin{aligned}
& \text { 4. }
\end{aligned}
$$

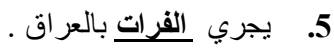

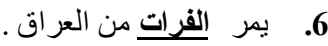

\begin{tabular}{|c|c|c|c|c|c|c|c|c|c|c|}
\hline \multirow{3}{*}{ Title } & \multirow{4}{*}{ No } & \multicolumn{7}{|c|}{ Reference } & \multicolumn{2}{|c|}{ Trans. } \\
\hline & & \multicolumn{3}{|c|}{ Generic } & \multicolumn{3}{|c|}{ Specific } & \multirow{2}{*}{ Unique } & \multirow{2}{*}{ FE. } & \multirow{2}{*}{ DE } \\
\hline & & definite & Indefinite & Zero & definite & Indefinite & Zero & & & \\
\hline \multirow[t]{3}{*}{$\begin{array}{l}\text { SL Text } \\
\text { English }\end{array}$} & & & & & & & & + & & \\
\hline & 1 & & & & & & & + & + & \\
\hline & 2 & & & & & & & + & + & \\
\hline
\end{tabular}

Text Analysis (6): 
TL Texts

Arabic

\begin{tabular}{|l|l|l|l|l|l|l|l|l|l|}
\hline 3 & & & & & & & + & + & \\
\hline $\mathbf{4}$ & & & & & & & + & + & \\
\hline $\mathbf{5}$ & & & & & & & + & + & \\
\hline $\mathbf{6}$ & & & & & & & + & + & \\
\hline
\end{tabular}

The Proposed Rendering:

يجري الفرات عبر الأراضي العراقية .

7. The House of Commons held a general conference yesterday. (Yeom, 1998: 59).

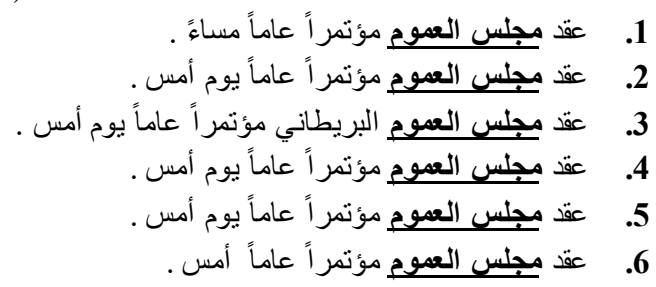

Text Analysis (7):

\begin{tabular}{|c|c|c|c|c|c|c|c|c|c|c|}
\hline \multirow{3}{*}{ Title } & \multirow{4}{*}{ No } & \multicolumn{7}{|c|}{ Reference } & \multicolumn{2}{|c|}{ Trans. } \\
\hline & & \multicolumn{3}{|c|}{ Generic } & \multicolumn{3}{|c|}{ Specific } & \multirow{2}{*}{ Unique } & \multirow{2}{*}{ FE } & \multirow{2}{*}{ DE } \\
\hline & & definite & Indefinite & Zero & definite & Indefinite & Zero & & & \\
\hline $\begin{array}{l}\text { SL Text } \\
\text { English }\end{array}$ & & & & & & & & + & & \\
\hline \multirow{6}{*}{$\begin{array}{c}\text { TL Texts } \\
\text { Arabic }\end{array}$} & 1 & & & & & & & + & + & \\
\hline & 2 & & & & & & & + & + & \\
\hline & 3 & & & & & & & + & + & \\
\hline & 4 & & & & & & & + & + & \\
\hline & 5 & & & & & & & + & + & \\
\hline & 6 & & & & & & & + & + & \\
\hline
\end{tabular}

The Proposed Rendering:

عقد مجلس العموم مؤتمر اً عاماً يوم أمس .

8. Have you seen Buckingham Palace ? (Yeom, 1998: 60).

1 . هل شاهدت قصر بكنكهام ؟

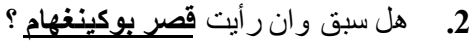

3.

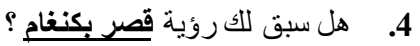

5.

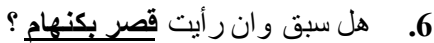

Text Analysis (8): 


\begin{tabular}{|c|c|c|c|c|c|c|c|c|c|c|}
\hline \multirow{3}{*}{ Title } & \multirow{4}{*}{ No } & \multicolumn{7}{|c|}{ Reference } & \multicolumn{2}{|c|}{ Trans. } \\
\hline & & \multicolumn{3}{|c|}{ Generic } & \multicolumn{3}{|c|}{ Specific } & \multirow{2}{*}{ Unique } & \multirow{2}{*}{ FE } & \multirow{2}{*}{ DE. } \\
\hline & & definite & Indefinite & Zero & definite & Indefinite & Zero & & & \\
\hline $\begin{array}{l}\text { SL Text } \\
\text { English }\end{array}$ & & & & & & & & + & & \\
\hline \multirow{6}{*}{$\begin{array}{c}\text { TL Texts } \\
\text { Arabic }\end{array}$} & 1 & & & & & & & + & + & \\
\hline & 2 & & & & & & & + & + & \\
\hline & 3 & & & & & & & + & + & \\
\hline & 4 & & & & & & & + & + & \\
\hline & 5 & & & & & & & + & + & \\
\hline & 6 & & & & & & & + & + & \\
\hline
\end{tabular}

The Proposed Rendering:

9. Mount Everest is the highest mountain in the world. (Yeom, 1998: 63).

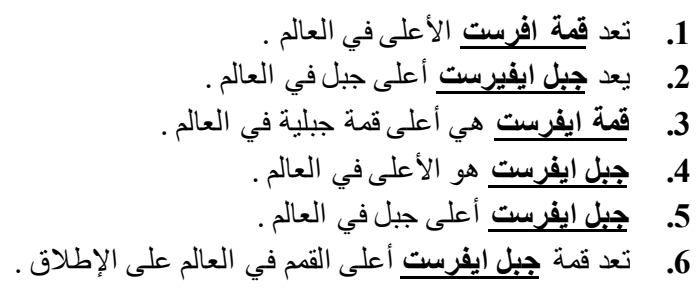

Text Analysis (9):

\begin{tabular}{|c|c|c|c|c|c|c|c|c|c|c|}
\hline \multirow{3}{*}{ Title } & \multirow{4}{*}{ No } & \multicolumn{7}{|c|}{ Reference } & \multicolumn{2}{|c|}{ Trans. } \\
\hline & & \multicolumn{3}{|c|}{ Generic } & \multicolumn{3}{|c|}{ Specific } & \multirow{2}{*}{ Unique } & \multirow{2}{*}{ FE. } & \multirow{2}{*}{ DE } \\
\hline & & definite & Indefinite & Zero & definite & Indefinite & Zero & & & \\
\hline $\begin{array}{l}\text { SL Text } \\
\text { English }\end{array}$ & & & & & & & & + & & \\
\hline \multirow{4}{*}{ TL Texts } & 1 & & & & & & & + & + & + \\
\hline & 2 & & & & & & & + & + & \\
\hline & 3 & & & & & & & + & & + \\
\hline & 4 & & & & & & & + & + & \\
\hline
\end{tabular}




\begin{tabular}{|l|l|l|}
\hline 5 & & \\
\hline 6 & & \\
\hline
\end{tabular}

The Proposed Rendering:

\section{FINDINGS AND DISCUSSION}

Our corpus analysis of the text examples reveals the following findings:

\section{Generic Reference / Definite:}

The definite article "the" in English has been replaced by the definite article " أل التعريف" by all subjects as far as examples 1,2,4,5,6,7 and 8 are concerned. In regard to example (3), it seems that only two subjects, namely (1) and (6) have replaced the definite article "the" by " . Thus, one can say that there is one-to-two correspondence between English and Arabic in regard to definite generic reference. This confirms what we have said in our literature review (section 2.12 page 49).

\section{Generic Reference / Indefinite:}

Subjecting these sentences to close scrutiny, one can see that the indefinite article "a" in English has been replaced by the definite article "the" in Arabic in regard to examples $1,3,7$, and 8 by all subjects. This may be due to the fact that Arabic lacks the indefinite article. As for example (5), it seems that all subjects have replaced the indefinite Article in English by the indefinite marker in Arabic which is "التنوين" (nunnation).

In regard to examples $2,4,6$, it seems that subjects are of two groups. The first group have replaced the indefinite article "a" by the definite article "the" as in the case of subjects $1,3,5$, in example 2 ; subject 3 in example 4 ; and subjects $1,2,3,5$, and 6 in example 6 . As for the second group, it seems that they have used the indefinite marker "التنوين" (nunnation) instead of the indefinite article "a". This means that there is no one-to-one correspondence between English and Arabic as far as indefinite generic reference is concerned.

\section{Generic Reference / Zero " $\varnothing$ " or "Some" :}

Judging from the respondents' renderings, one can say that all subjects in examples 2,4,5,6,7,8,9 and 11 have replaced the zero article " $\varnothing "$ " in English by the definite article "أل التعريف in Arabic. This confirms what we have already mentioned in our literature review (see page 44). Concerning examples 1 and 3, it seems that all subjects are after approximate formal correspondence. For this reason they have used "بعض الخبز" in example 1 and "بعض البطيخ" in example 3. However the head of the noun phrase in English is used with zero article " $\varnothing$ ", whereas in Arabic, it is used with the definite article "the" by all subjects.
Regarding example 10, it seems that subjects 1 and 6 are after achieving approximate formal correspondence. For this reason, they have used “" "أهكان ويلز “, , whereas the rest of subjects in this example have replaced the zero article " Ø" by the definite article "أل التعريف" . This means that there is no one-to-one correspondence between English and Arabic with regard to generic reference / zero article. And this reinforces what we have already said (see page 44).

\section{Specific Reference / Definite:}

Close scrutiny of the English examples 1,4,6,10 presented in this section with their Arabic renderings reveal that all subjects are after achieving approximate formal correspondence. For this reason, they have replaced the definite article in English "the" by "أل التعريف" in Arabic which substantiates the view that formal correspondence can somehow be achieved as far as the definite specific reference is concerned. And this comes in an agreement with our literature review.

As for examples 3,7,8 and 11, it seems that all subjects have replaced the definite article "the" in English by "التعريف بالإضافة" in Arabic in order to achieve definiteness in specific reference. Concerning example 2, it seems that subjects $2,3,4,5$ have replaced the definite article "the" by "التعريف بالإضافة", whereas subjects 1 and 6 have used zero article. Regarding example 5, it seems that subjects $1,4,5$, and 6 are seeking formal correspondence since they have replaced the definite article “the” by Arabic definite article "أل التعريف", while subjects 2 and 3 have used "التعريف بالإضافة"

instead of the definite article. This confirms that there is one-to-two correspondence between English and Arabic regarding the definite specific reference.

In regard to example 10 , it seems that all subjects have used zero translation because of certain grammatical restrictions in Arabic in that Arabic does not use the definite article with most proper nouns.

\section{Specific Reference / Indefinite:}

Of the eight English sentences with their Arabic renderings presented in this section, one can say that all subjects in examples 2 and 3 have replaced the indefinite article "a" by the indefinite marker "التنوين" (nunnation). This type of equivalence is called nil-equivalence, simply, because Arabic lacks indefinite articles. Concerning 
example 7 , one can see that all subjects have replaced the indefinite article by the definite article. So the indefinite specific reference has become definite specific reference. Regarding example 8 , it seems that all subjects have replaced the indefinite article "a" by zero article. This means that all subjects have used nil-equivalence because the indefinite article does not exist in Arabic. As for example 6 , it seems that only subject 2 has replaced the indefinite article by "التعريف بالإضافة", while the rest of the subjects have replaced the indefinite article "a" by the indefinite marker "التنوين" (nunnation) because Arabic lacks this article.

In example 1 , it seems that only subject 5 has replaced the indefinite article "a" by the indefinite marker "التنوين" (nunnation), while the rest of the subjects have replaced the indefinite article " $a$ " by zero article " $\varnothing$ ". In example 4 , one can see that subjects 2,3 , and 4 have replaced the indefinite article "a" by the indefinite marker "التنوين" (nunnation), while subjects 1, 5, and 6 have replaced the indefinite article by the definite article “"أل التعريف". Concerning example 5, one can say that subjects 1,3 , and 4 have replaced the indefinite by the definite article "أل التعريف, whereas subjects 2, 5, and 6 have used "التنوين" (nunnation) instead of the indefinite article.

One can generalize that the indefinite article in English does not have an equivalence in Arabic; therefore, translators resort either to use of the indefinite marker " or the definite article " or "التعريف التعريف " "بالإضافة . This leads us to say that there is one-to-many correspondence between English and Arabic.

\section{Specific Reference / Zero Article "}

A close inspection of the English examples 2, 4, 6, 7, 9, and 10 with their renderings, reveals that all subjects have replaced zero article by the definite article "أل التعريف" . This is due to certain grammatical restrictions in Arabic language. As for example 3, it seems that all subjects have replaced the zero article by "التعريف بالإضافة" . Concerning examples 5 and 8 , it seems that all subjects are after achieving formal correspondence. In regard to example 1, all renderings reveal that all subjects have replaced the zero article by "التعريف بالإضافة" . In example 11, one can see that subject 1 has replaced the zero article by the definite article ". This confirms what we have already mentioned in our literature review, whereas the rest of the subjects have replaced the zero article by the indefinite marker "التنوين" (nunnation).

\section{Unique Reference:}

Working through these examples carefully, one soon notices that all subjects have achieved a formal correspondence in that zero article has been replaced by zero article. As for example 2, it appears that all subjects have replaced the zero article by the definite article " أل "التعريف" The same thing can be said about example 5. In example 6 , it is apparent that all subjects have achieved a formal correspondence in that the definite article "the" in English has been replaced by “ "أل التعريف in Arabic. Regarding example 7, one can realize that all subjects have replaced the definite article "the" by "التعريف بالإضافة" . In examples 8 and 9, it seems that all subjects have replaced the zero article by "التعريف بالإضافة" .

As far examples 3 and 4, one can notice that all subjects have replaced the definite article "the" in English by "التعريف بالإضافة" in Arabic. Hence one can generalize that as far as unique reference is concerned, there is one-tomany correspondence between English and Arabic. This can be attributed to the morphological restrictions that affect the nature of proper nouns.

\section{CONCLUSIONS}

The current study has come up with the following conclusions:

1. Reference in both English and Arabic is of three types, namely (a) generic both definite and indefinite, (b) specific both definite and indefinite, and (c) unique.

2. Articles in English are of three types (a) the definite article "the", (b) the indefinite article "a / an", and (c) the zero article. These are realized in Arabic by using " , indefinite marker

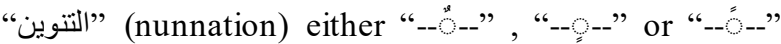
according to conditioning factors such as cotext and context.

3. Despite the fact that there is a one-to-one correspondence between the English definite article "the" and the Arabic definite article "أل التعريف" on the word rank as well as phrase rank, this generalization does not always work, since in many cases the translation equivalence of the English zero article happens to be definite article in Arabic (see our data analys is).

4. With reference to definite generic reference there is a formal correspondence (i.e., one-to-one correspondence) between the definite article in English and its equivalence "أل التعريف" in Arabic.

5. In most indefinite generic reference cases the indefinite article "a / an" has been replaced by the definite article "the". This confirms the view that formal correspondence cannot be achieved since Arabic lacks the indefinite article. 
6. In generic reference, zero article " $\varnothing$ " in English has been replaced either be the definite article "أل التعريف" or "التعريف بالإضافة" . This means that achieving formal correspondence is not possible in this case.

7. As far as definite specific reference is concerned, formal correspondence has been achieved by most subjects with few exceptions.

8. In regard to indefinite specific reference, it is not possible to achieve formal correspondence since Arabic lacks the use of indefinite article.

9. Formal correspondence cannot be achieved as far as specific reference "zero" article is concerned. This fact is revealed from the replacement of the zero article by the definite article "الن التعريف" and "التعريف بالإضافة" .

10. Formal correspondence cannot be achieved as far as unique reference is concerned. This is because of the nature of a variety of proper nouns that have in both languages different forms.

\section{RECOMMENDATIONS FOR PEDAGOGICAL IMPLICATIONS}

On the basis of our findings and our conclusions, we put forward the following recommendations:

1. Translators, students and teachers of translation, as well as contrastive analysts are supposed to have a thorough knowledge of articles systems and functions in both English and Arabic. They should also be acquainted with the partial similarities and partial differences between article systems and functions in English and Arabic.

2. Translators in general and learners in particular should be familiarized with nouns and noun phrases in English and Arabic whether they are premodified or postmodified, definite or indefinite. They also should be familiarized with the type of reference, i.e., generic both definite and indefinite, specific both definite and indefinite as well as unique reference.

\section{SUGGESTIONS FOR FURTHER STUDIES:}

Although the current thesis is a comprehensive study, it cannot be considered as a final one naturally, some cases and areas have been left to be tackled for further research.

1. A similar study can be carried out to study the translation of the articles from Arabic into English.

2. The translation of articles can be also studied in other genres such as literary texts and Qur'a:nic texts.

3. A comprehensive study can be also conducted about definiteness and indefiniteness and pragmatic, logical and semantic factors that affect the specification of their nature.

4. A study of a presuppositional analysis of specific indefiniteness can be conducted.

5. A study of a presuppositional analysis of specific definiteness can be carried out.

\section{REFERENCES}

[1] Abusch, D. (1994): "The Scope of Indefinites". In: Natural Language Semantics, Vol. 2, pp. 83-135.

[2] Allsop, J. (1983): Cassell's Student's English Grammar, London: Cassell Publishers Limited.

[3] AL-Naqqash, Z. (2000): The Arabic Cognate Object in English Arabic Translation. (Unpublished M. A. Thesis) University of AL-Mustansiriyya.

[4] AL-Sulaimaan, M. D. (2002): "A Linguistic Study of Errors in the Use of Articles Committed by Arabicspeaking Students at the English B.A First-Year level (University of Mosul)". In: Adab AL-Rafidayn Vol. 35, pp.23-50.

[5] Azar, B. S. (1992): Fundamentals of English Grammar, London: Longman Group Ltd.

[6] Aziz, Y. Y. (1979): "English Articles: A Problem for the Iraqi Learners". In Journal of Education and Science, Vol.1, pp. 19-28.

[7] Aziz, Y. Y. (1989): A Contrastive Grammar of English and Arabic, Mosul: Mosul University Press.

[8] Baker, M. (1992): In Other Words: A Course Book on Translation, New York: Routlege, Chapman and Hall, Inc.

[9] Beeston, A. F. (1970): The Arabic Language Today, London: Hutchinson Co. Ltd.

[10] Benita (2004). An Online Catalogue of English Grammar Exercises. Internet.

[11] Biber, D. , Johansson, S., Leech, G., Conrad, S. and Fineegan, E. (2000): Longman Grammar of Spoken and Written English, Harlow: Pearson Education Limited.

[12] Chierchia, G. (1995): Dynamics of Meaning: Anaphora, Presupposition and Syntactic Theory, Chicago: Chicago University Press.

[13] Chierchia, G. and McConnell-Ginet, S. (1990): Meaning and Grammar: An Introduction to Semantics Cambridge, MA: MIT Press.

[14] Chung, S. and Pullum, G. (2002): Grammar, New York: University of California.

[15] Cornish, F. (1986): Anaphora Relations in English and French A Discourse Perspective, London: Croom Helm. 
[16] Crystal, D. (2003): A Dictionary of Linguistics and Phonetics, Oxford: Oxford Basil Blackwell (Fifth Edition).

[17] Declerck, R. (2000): A Model of the English Tense System, Belgium: (K.U.L.).

[18] Diesing, M. (1992): Indefinites, Cambridge: MTT press.

[19] Eastwood, J. (2000): Oxford Guide To English Grammar, Oxford: Oxford University Press.

[20] Eco, U. (1995): The Search for the Perfect Language, Oxford: Oxford Basil Blackwell.

[21] Enc, M. (1991): “The Semantics of Specificity". In: Linguistic Inquiry, Vol. 22, pp. 1-26.

[22] Farghal, M. (1993): "Meaning in Translation: A Theoretical Model". In: Meta, xxxviii, 2, pp. 252-267.

[23] Farghal, M. and Shunnaq, A. (1999): Translation with Reference to English and Arabic: A Practical Guide. Irbid: Dar AL-Hilal for Translation.

[24] Finch, G. (2000): Linguistic Terms and Concepts, New-York: St. Martin's Press Inc.

[25] Graig, C. (1986): Noun Classes and Categorization, Amsterdam: Benjamins.

[26] Haegeman, L. and Gueron, J. (1999): English Grammar: A Generative Perspective, Oxford: Oxford Blackwell Ltd.

[27] Hansard, M. (2003): Adjective or Adverb, Paris: Owl at Pur due University.

[28] Hatim, B. and Mason, I. (1997): The Translator as Communicator, London: Routledge.

[29] Heim, I. (1982): The Semantics of Definite and Indefinite Noun Phrases, (Published Doctoral Dissertation), Amherst: University of Massachusetts Press.

[30] Heim, I. (1983): "On the Projection Problem for Presupposition". In: Proceeding of the Second West Coast Conference on Formal Linguistics, pp. 114125.

[31]Heim, I. (1987): "Where Does the Definiteness Restriction Apply. Evidence from the Definiteness of Variables". In: Reuland, E and Meulen, A. G. (eds.). The Representation of Indefinites, pp. 21-42.

[32] Heim, I. (1991): "Articles and Definiteness". In: Semantics; An International Handbook of Contemporary Research, Berlin: de Gruyter, pp. 5674.

[33] Heim, I. (1992): "Presupposition Projection and the Semantics of Definitenes s". In: Journal of Semantics, Vol. 9, pp. 183-221.
[34] Henkin, B., (1998): "Narrative Style of Palestinian Bedouin Adults and Children". In: Pragmatics, Vol. 8, No. 1, pp. 47-78.

[35] Hongwei, C. (1999): "Cultural Differences and Translation” In: Meta, XLIV, 1, pp. 1-30.

[36] Hoop, H. (1992): Case Configuration and Noun Phrase Interpretation, (Published Doctoral Dissertation,) University of Groningen.

[37] Huang, Y. (1994): The Syntax and Pragmatics of Anaphora, Cambridge: Cambridge University Press.

[38] Ilyas, A. I. (1985): "Some Remarks About the English Definite Article "the" and Arabic /?al/, with Reference to Translation" In: AL-Mustansiriya Literary Review, Vol. 11, pp. 27-49.

[39] Jacobson, R. (1959): On Linguistic Aspects of Translation:. In: R.A. Brower (ed.), on Translation, pp. 114-120.

[40] Joodi, A. M. (1978): A Contrastive Analysis of the Articles System in Standard English Modern Standard Arabic, (Unpublished M.A Thesis) University of Baghdad.

[41] Kamal, S. (1999): "What Is Your Translation Metholodogy". In: The Ata Chronicle, Vol. 28, No. 2, pp. 40-45.

[42] Kaplan, D. (1989): "Demonstratives". In: Almog, J., Perry, J. and Wettstein (eds.), Themes from Kaplan, pp. 481-563.

[43] Karamanian, A. P. (2005): "Translation and Culture". In: Translation Journal, Vol. 6, pp. 242-261.

[44] Kharma, N. (1981): "Analysis of the Errors Committed by Arab University Students in the Use of the English Definite / Indefinite Articles. In: IRAL, Vol. xix, pp. 333-343.

[45] Kremers, J. (2000): a Recursive Linearization Approach to Arabic Noun Phrase, Nijmegen: University of Nijmegen Press.

[46] Kussmaul, P. (1995): "Training the Translator", Benjamin Translation Liberary, 10, Benjamins: Amesterdam, 177 pp. 54-71.

[47] Larson, R. K. (2000): Semantics of Adjectival Modification, Amsterdam: Orleans Press.

[48] Leech, G. and Svartvik, J. (1994): A Communicative Grammar of English, London: Longman Group Ltd.

[49] Linsky, L. (1979): Reference and Modality, London: Oxford University Press.

[50] Lyons, J. (1991): Natural Language and Universal Grammar: Essays in Linguistic Theory, Cambridge: Cambridge University Press. 
[51] Master, P. (1988): "Teaching the English Article System, Part 1". In: English Teaching Form, Vol. xxxvi, No. 2, pp. 2-7.

[52] Murphey, R. and Smalzer, W. (2003): Basic Grammar in Use, Cambridge: Cambridge University Press.

[53] Neuman, D. M. (1981): English Grammar for Proficiency, Surrey: Thomas Nelson, Sons Ltd.

[54] Newmark, (1991): About Translation, Hertforshire: Longman Group Ltd.

[55] Newmark, (1988a): A Text Book of Translation, London: Prentice Hall International Ltd.

[56] Newmark, P. (1988b): Approaches to Translation, London: Prentice Hall International Ltd.

[57] Nida, E. and Taber, (1969): The Theory and Practice of Translation, Leiden: E. J. Brill Press.

[58] Nida, E., (1964): Towards the Science of Translation, Leiden: E. J. Brill Press.

[59] O’Connor, J. (1980): Better English Pronunciation, Cambridge: Cambridge University Press.

[60] Parrot, M. (2000): Grammar for English Language Teachers, Cambridge: Cambridge University Press.

[61] Potts, T. (1994): Structure and Categories for the Representation of Meaning, Cambridge: Cambridge University Press.

[62] Quirk, R. and Greenbaum, S. (1973): A University Grammar of English, London: Longman Group Ltd.

[63] Quirk, R. Greenbaum, S. Leech, G. and Svartvik, J. (1972): A Grammar of Contemporary English, London: Longman Group Ltd.

[64] Radford, A. (1997): Syntax, Cambridge: Cambridge University Press.

[65] Reimer, M. (1991): "Demonstratives, Demonstrations, and Demonstrata". In: Philosophical Studies, Vol. 62, No. 2, pp. 187-202.

[66] Reimer, M. (1992): "Three Views of Demonstrative Reference”. In: Synthèse, Vol. 93, No. 3, pp. 373-402.

[67] Reinhart, T. (1983): Anaphora and Semantic Interpretation, Chicago: Chicago University Press.

[68] Roach, P. (1983): English Phonetics and Phonology, Cambridge: Cambridge University Press.

[69] Schiffrin, D. (1994): Approaches to Discourse, Oxford: Blackwell Publishers.

[70] Sinclair, J. (1990): Collins Cobuild English Grammar, London: Cobuild Co-Ltd.

[71] Swan, M. (1996): Practical English Usage, Oxford: Oxford University Press.

[72] Trask, R. (1993): A Dictionary of Grammatical Terms in Linguistics, London: Routledge.
[73] Ward, G. L. and Prince, E. F. (1991): "On the Topicalization of Indefinite NPs". In: Journal of Pragmatics, Vol. 6, pp. 167-177.

[74] Wilson, G. (1997): "On Definite and Indefinite Descriptions". In: Philosophical Review, Vol. 87, pp. 48-76.

[75] Wood, E. and Mcleod, N. (1990): Using English Grammar: Meanings and Form, London: Prentice Hall International Ltd.

[76] Wright, W. (1971): A Grammar of the Arabic Language, Cambridge: Cambridge University Press.

[77] Yeom, J. I. (1998): A Pre-suppositional Analysis of Specific Indefiniteness, New York: Garland Publishing, Inc.

[78] Zandvoort, R. W. (1972): A Handbook of English Grammar, London: Longman Group Ltd. 